\title{
Tropical cyclones and climate change
}

\author{
Kevin J.E. Walsh, ${ }^{1}$ John L. McBride, ${ }^{2}$ Philip J. Klotzbach, ${ }^{3}$ \\ Sethurathinam Balachandran, ${ }^{4}$ Suzana J. Camargo, ${ }^{5}$ Greg Holland, ${ }^{6}$ \\ Thomas R. Knutson, ${ }^{7}$ James P. Kossin, ${ }^{8}$ Tsz-cheung Lee, ${ }^{9}$ \\ Adam Sobel ${ }^{10}$ and Masato Sugi ${ }^{11}$
}

Edited by Matilde Rusticucci, Domain Editor, and Mike Hulme, Editor-in-Chief

Recent research has strengthened the understanding of the links between climate and tropical cyclones (TCs) on various timescales. Geological records of past climates have shown century-long variations in TC numbers. While no significant trends have been identified in the Atlantic since the late 19th century, significant observed trends in TC numbers and intensities have occurred in this basin over the past few decades, and trends in other basins are increasingly being identified. However, understanding of the causes of these trends is incomplete, and confidence in these trends continues to be hampered by a lack of consistent observations in some basins. A theoretical basis for maximum TC intensity appears now to be well established, but a climate theory of TC formation remains elusive. Climate models mostly continue to predict future decreases in global TC numbers, projected increases in the intensities of the strongest storms and increased rainfall rates. Sea level rise will likely contribute toward increased storm surge risk. Against the background of global climate change and sea level rise, it is important to carry out quantitative assessments on the potential risk of TC-induced storm surge and flooding to densely populated cities and river deltas. Several climate models are now able to generate a good distribution of both TC numbers and intensities in the current climate. Inconsistent TC projection results emerge from modeling studies due to different downscaling methodologies and warming scenarios, inconsistencies in projected changes of large-scale conditions, and differences in model physics and tracking algorithms. () 2015 Wiley Periodicals, Inc.

\author{
How to cite this article: \\ WIREs Clim Change 2016, 7:65-89. doi: 10.1002/wcc.371
}

\footnotetext{
*Correspondence to: kevin.walsh@unimelb.edu.au

${ }^{1}$ School of Earth Sciences, University of Melbourne, Parkville, Australia

${ }^{2}$ Centre for Climate Research Singapore (CCRS), Meteorological Service Singapore, Singapore, Singapore

${ }^{3}$ Department of Atmospheric Science, Colorado State University, Fort Collins, CO, USA

${ }^{4}$ Cyclone Warning Research Centre, Regional Meteorological Centre, Chennai, India

${ }^{5}$ Lamont-Doherty Earth Observatory, Columbia University, Palisades, NY, USA

${ }^{6}$ National Center for Atmospheric Research, Boulder, CO, USA
}

\footnotetext{
${ }^{7}$ National Oceanic and Atmospheric Administration (NOAA), Geophysical Fluid Dynamics Laboratory, Princeton, NJ, USA

${ }^{8}$ National Oceanic and Atmospheric Administration (NOAA), National Centers for Environmental Information, Asheville, NC, USA

${ }^{9}$ Hong Kong Observatory, Hong Kong, China

${ }^{10}$ Columbia University, Palisades, NY, USA

${ }^{11}$ Meteorological Research Institute, Japan Meteorological Agency, Ibaraki, Japan

Conflict of interest: The authors have declared no conflicts of interest for this article.
} 


\section{INTRODUCTION}

E stimates of the effect of anthropogenic climate change on tropical cyclones (TCs) generally fall into two main topics: whether changes in the climate to date have already had a detectable effect on TCs and what portion of this is due to anthropogenic or natural causes, and how climate change might affect TCs in the future. Assessments of observed trends in TC characteristics are affected by the same data homogeneity issues that affect all climate variables, so that a starting point for such an analysis is the construction of a dataset that is free from spurious trends due to changes in observing and assessment practices. These issues are important for TCs, as the most comprehensive datasets of TC records, the best track datasets, ${ }^{1}$ were designed as best estimates of TC data using the techniques available at the time of compilation. Thus, they were not primarily intended as datasets to be used for trend analysis. Nevertheless, recent advances in the production of more temporally homogeneous datasets have been made, and analysis of these datasets is starting to reveal important new results. ${ }^{2,3}$ The increasing use of atmospheric reanalysis datasets ${ }^{4-9}$ has facilitated analysis of the impact of changes in climate variables on TCs, although reanalyses have significant potential homogeneity issues relevant to TC activity. ${ }^{10,11}$ Current reanalysis products have substantial limitations in their explicit representation of TCs, ${ }^{12}$ and their performance in representing various TC climatological metrics varies among available reanalyses. ${ }^{13}$ Efforts have also been made using geological techniques to determine TC incidence in the distant past, and these studies have revealed surprisingly large long-term variations in past TC activity. ${ }^{14-16}$

For future projections of TCs, climate models (general circulation models or GCMs) have improved to the point where the best models can now give reasonable simulations of numbers of the average number of TCs in all TC basins, including their year-to-year variability. ${ }^{17,18}$ While there is still room for improvement, global GCMs are also showing an increasing ability to simulate the intensity distribution of observed TCs in both SST-forced ${ }^{19}$ and coupled $^{20}$ configurations. This latter task in particular requires high model resolution, so various dynamical, ${ }^{21}$ statistical, ${ }^{22,23}$ and hybrid ${ }^{5}$ 'downscaling' techniques have been developed to bridge the gap between the relatively low resolution of most climate models (e.g., the CMIP5 models used for many climate change projections ${ }^{24}$ ) and the fine detail required for reliable simulation of TC intensities, an important capability for future climate projections of TCs.
Confidence in future projections has been increased by theoretical ideas and techniques that relate climate variables to TCs. These have enabled both a better understanding of TC dynamics and improved confidence in future projections. While a generally accepted climate theory of TC formation is still lacking, a climate theory of TC maximum intensity (potential intensity, PI) is now well established. $^{25,26}$ Analysis and model experiments are beginning to determine the crucial climate variables associated with changes in TC formation rate.

This review summarizes recent research in the interdisciplinary field of TCs and climate change. It does not attempt an updated assessment of the science beyond that given in the IPCC 5th Assessment Report $^{27}$; i.e., this review does not make synthesis statements regarding our overall level of confidence in predictions of climate change science. Nevertheless, this review is motivated by recent developments in this field since the previous review and assessment. ${ }^{28}$ The increasing compilation and analysis of improved, more homogeneous TC datasets has enabled more conclusive results to be produced about TC trends. There is an increasing availability of datasets from before the period of written records. Additionally, the best-performing climate modeling systems are now producing not only a good simulation of numbers and geographical patterns of TC formation but also a rapidly improving representation of the distribution of TC intensity. These three developments motivate a new review of this topic.

\section{OBSERVATIONS OF TCS}

\section{Paleotempestology}

Paleotempestology is the study of storm occurrence in the past before written records became available. The purpose of paleotempestology is to establish whether there have been variations in the number and intensity of TCs over geologic time periods. This provides a way of establishing a longer climate baseline than the relatively short observational record and also for exploring the dependence of TC activity on climate change. Many types of geological proxies have been tested for reconstructing past hurricane activity; the most common proxies are based on hurricane-induced overwash deposits of sediments of coastal lakes and marshes. ${ }^{16,29,30}$ Other emerging proxies are based on oxygen isotopic ratios of hurricane precipitation in caves (stalagmites), tree rings, and corals. ${ }^{15,31,32}$ As these studies typically focus on a specific geographic location, a caveat that should be considered is that they cannot distinguish between 
basin-wide trends or variability and systematic changes in TC tracks, both of which may be modulated by climate. ${ }^{33}$ One method to evaluate the significance of the obtained patterns of overwash reconstructions is to employ a large set of synthetic hurricane tracks for a specific site. ${ }^{34}$

A number of significant recent advances have been made in this work. In the Australian region, oxygen isotopic analysis of stalagmite records has been used ${ }^{35}$ to infer that the TC incidence in northeast Queensland is less at present than at any time in the past 1500 years. In the Atlantic basin, e.g., Brandon et al. ${ }^{30}$ use overwash deposits to show that a period of increased intense hurricane frequency is observed between $\sim 1700$ and $\sim 600$ years before the present (B.P.) and decreased intense storm frequency is observed from $\sim 2500$ to $\sim 1700$ and $\sim 600$ years B.P. to the present. Thus, there have been large, unexplained variations in TC climatology in the relatively recent geologic past. ${ }^{16,29,36}$

These sedimentary records only go back a few millennia, however. Therefore, dynamical, ${ }^{37}$ statistical, $^{38}$ and statistical-dynamical ${ }^{39}$ modeling studies of more distant past climates have become more common. For both the Holocene $(6 \mathrm{ka}$ before the present) and the Last Glacial Maximum (LGM; $21 \mathrm{ka})$, Korty et al. ${ }^{40,41}$ show that even though conditions during the LGM were cooler than today, there was not a systematic decrease in either PI or other environmental variables associated with TC frequency. Sugi et al. $^{42}$ found that their modelsimulated TC frequency significantly increases in a $4 \mathrm{~K}$ cooler climate GCM experiment, indicating that there may be more TCs in a glacial period, consistent with the consensus finding that overall TC frequency decreases with warming ${ }^{43}$ and showing that a climate with generally cooler SSTs does not imply fewer TCs. ${ }^{44}$ They also pointed out that TC formation under these conditions can occur at sea-surface temperatures (SSTs) well below $26^{\circ} \mathrm{C}$, a value conventionally used to indicate the minimum threshold for TC formation in our present-day climate. ${ }^{45}$ Merlis $^{46}$ used the GFDL HiRAM model to show that TC frequency was simulated to increase during the LGM.

\section{Historical and Satellite Era}

Observed TC data during what is called the 'historical' era (in this case typically from the 19th century onward, the period when ship observations became more routine) are compiled in what is known as 'best track' datasets. These compilations are the best estimates of TC characteristics such as position and intensity, but are subject to ongoing review. ${ }^{47}$
The recent introduction of the IBTrACS compilation of best track datasets ${ }^{1}$ has considerably facilitated analysis of global climate trends. Creating an homogenous climate record from best track data continues to be a challenge, however, especially for cyclone intensity data, ${ }^{48}$ as the quality of measuring techniques has generally improved over time. The parallel creation of more homogeneous satellitederived datasets ${ }^{3}$ increasingly enables analysis of climate variability for the recent decades.

In addition to cyclone intensity, both size and translation speed have been shown to be substantial contributors to the impacts resulting from hurricane passage. ${ }^{49-52}$ Emphasis on increased attention to these parameters in the development of future datasets is therefore desirable, along with creative methods for developing new approaches to their determination from past climate. ${ }^{53}$ It has been shown that for observed Atlantic TC intensities and sea surface cooling due to the passage of a TC, storm translation speed affects the amount of local cooling, but the cooling does not increase monotonically for all intensities. ${ }^{54}$ This indicates a role for ocean subsurface thermal structure in modulating the ability of storms to intensify and thus alter the degree of cooling under intense TCs. ${ }^{55}$

\section{Global Observations}

A previous review of this topic ${ }^{28}$ concluded that it remains uncertain whether past changes in TC activity have exceeded the variability expected from natural causes.' While there remain concerns about the temporal homogeneity of the best track record, ${ }^{56,57}$ recent studies using satellite-based temporally homogenized datasets are beginning to suggest climate trends of various kinds in the TC record over the past few decades. For example, a summary of trends in the lifetime maximum intensity of TCTCs in various ocean basins ${ }^{3}$ is shown in Figure 1, for the period 1989-2009. Globally, there are modest significant trends in this quantity (at the $90 \%$ level), but individual basins have greater significance. In the North Atlantic and Western North Pacific, trends are highly significant at the $95 \%$ level, with increases in the North Atlantic and decreases in the Western North Pacific. More modest trends significant at the 90\% level are seen in the South Pacific and the South Indian basins (both upwards). Trends have not been significant in the Eastern North Pacific and the North Indian basin has insufficient data. More recently, Kossin et al. ${ }^{58}$ find significant poleward movement in the latitude of the maximum intensity of TCs over the period 1982-2012. This result is potentially important as an indicator of the poleward expansion 

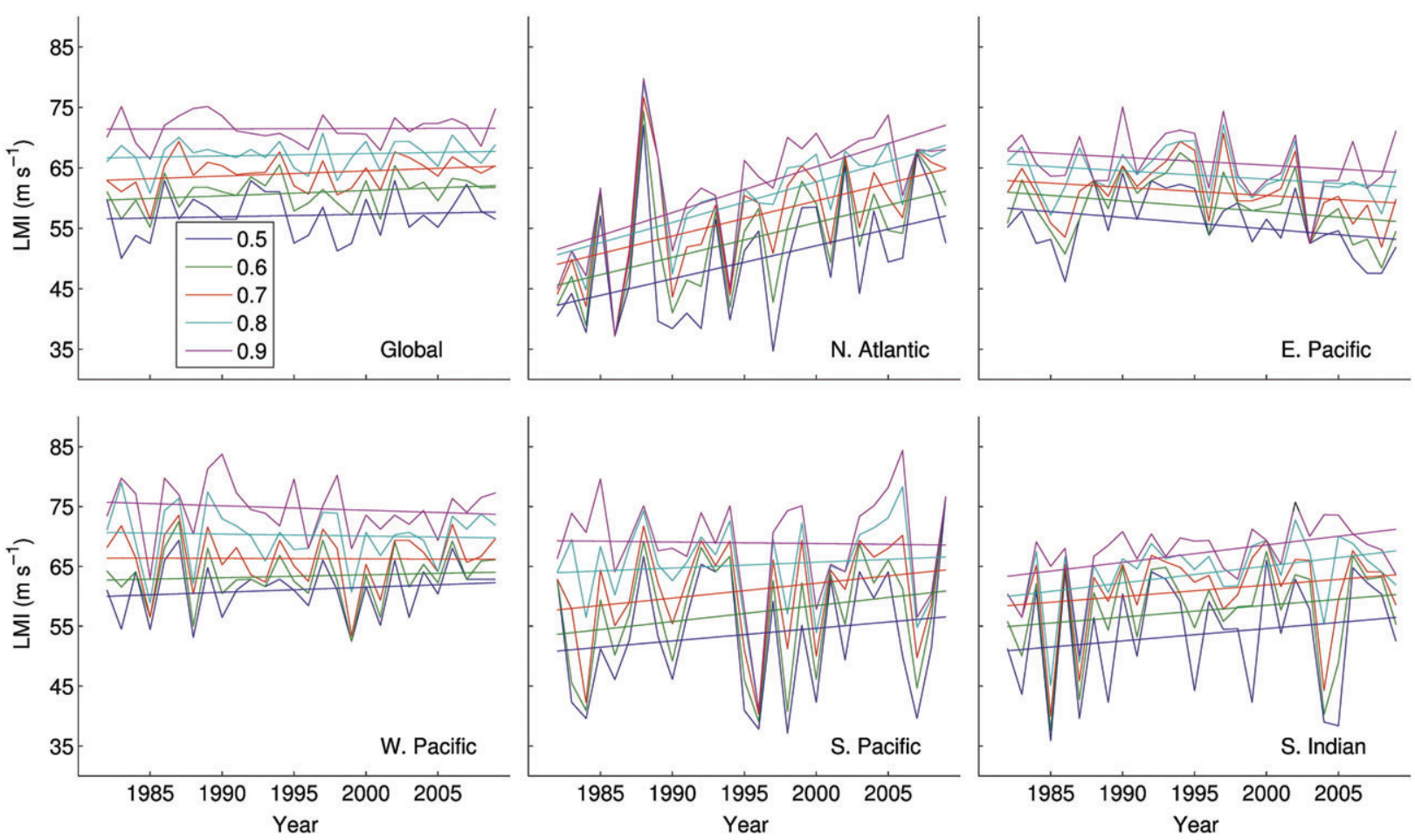

FIG URE 1 | Plots of quantiles (mean to 0.9) of the lifetime maximum intensity (LMI) of storms in the various tropical cyclone formation basins, from a homogenized satellite-based analysis of tropical cyclone intensity (1982-2009). (Reprinted with permission from Ref. 3 Copyright 2013 American Meteorological Society)

of the tropics, an outcome of anthropogenic climate change that is predicted by both theory ${ }^{99}$ and model projections. ${ }^{60}$ An expansion of the tropics implies a potential for TC effects to be felt further poleward in a warmer world. The causes of the observed trends have not been fully established, however. Holland and Bruyère $^{61}$ considered trends in numbers of intense TCs using an early version of the homogenized satellite-based dataset of Kossin et al. ${ }^{3}$ and in the IBTrACS data. ${ }^{1}$ They find substantial relationships between an index of global warming and the observed proportion of very intense TCs (SaffirSimpson categories 4 and 5) in the IBTrACS data from 1975 to 2010, and similar although smaller trends in the Kossin dataset. No change in global cyclone frequency or average intensity was found, but they concluded there has been a substantial increase in the proportion of intense hurricanes, both globally and individually in all basins except for the eastern North Pacific. This is consistent with trends in intense cyclones found by previous studies for individual basins. ${ }^{62-68}$ Recently, Klotzbach and Landsea $^{69}$ added an additional 10 years of data to the analysis of Webster et al., ${ }^{62}$ finding a flattening out of the upward trend in categories 4 and 5 storm numbers. They also find a continuation in the increasing trend in the proportion of these storms, but that this trend is not statistically significant during the more recent period 1990-2014. Since the early 1990s, global accumulated cyclone energy (ACE) values have undergone a fairly sizeable decrease, with 24-month running mean values in mid-2015 the lowest that they have been since the mid-1970s. ${ }^{70}$

\section{Western North Pacific}

Several recent reviews have been conducted on trends in the western North Pacific (WNP) region. ${ }^{71-73}$ There are several different best-track datasets that have been compiled for this region and they have differences in their representation of TC intensities. ${ }^{74}$ Existing datasets show pronounced inter-decadal variations in a number of TC metrics in the western North Pacific basin, such as storm frequency, intensity, and power dissipation index (PDI; a measure that combines TC intensity and frequency with lifetime). Multidecadal trends in WNP basin-wide TC frequency are highly dependent on which best track dataset is used. Among the four best track datasets assessed, the China Meteorological Administration (CMA, 1949-2010) and Hong Kong Observatory (HKO, 1961-2010) datasets show significant 
decreasing trends in TC (tropical storm or above) frequency, but for the Joint Typhoon Warning Center (JTWC, 1945-2010) and Regional Specialized Meteorological Center Tokyo (1977-2010) datasets only a nominal, statistically insignificant decreasing trend was found. Hsu et al. ${ }^{75}$ reported an abrupt decrease in the late-season TC frequency that is consistent among best track datasets. Causes for interdecadal changes in typhoon genesis in the WNP have been examined by Choi et al. ${ }^{76}$ who conclude that the horizontal distribution of SST, as opposed to its magnitude, can be a key factor.

For TC intensity, trends in intense categories 4-5 typhoon frequencies in the WNP are particularly divergent among datasets in recent decades, and so remain uncertain. Increasing trends in intense typhoon frequencies in the WNP have been found by a number of studies. ${ }^{61-66}$ However, these trends are not apparent in all the datasets available for the basin, ${ }^{74}$ and satellite-based intensity trends since $1981^{3}$ show more modest trends.

Efforts have been made to reconcile the differences in intensities of WNP TCs from the various agencies using a quantile method, ${ }^{64}$ whereby more agreement is shown between the various best track datasets in this region when intensity ranks are used rather than raw intensity estimates themselves. Kang and Elsner ${ }^{64}$ showed that the statistical analysis of consensus trends between the JWTC and JMA datasets indicate fewer but stronger storms since 1984. Nevertheless, the continued discrepancies between the various datasets in the WNP region continue to be a matter of concern.

In principle, a good numerical simulation of TC trends in this basin could help resolve some of these issues. Wu and $\mathrm{Zhao}^{66}$ used the Emanuel et al. ${ }^{5}$ statistical downscaling approach to examine recent TC trends for the WNP. They found an increasing intensity trend that was similar to though less than that in the JTWC data archive. This trend was not consistent with the decreasing or zero trends in other available datasets for the region. Reconciling the substantial differences in WNP TC archives would aid future research in this area.

Despite the uncertainty in basin-wide changes in TCs, observations indicate some regional shifts in TC activity in the basin, such as a decreasing trend in TC occurrence in part of the South China Sea and an increasing trend along the east coast of China during the past 40 years. This change is apparently related to local circulation variations in eastern Asia and the WNP. ${ }^{71,72,77}$ Further observations and research will still be required to understand the influence and contribution of natural variability and anthropogenically forced climate change on TC track changes in the WNP. Kossin et al. ${ }^{58}$ identified a poleward migration over the past 30 years or so of around $0.5^{\circ}$ latitude per decade in the location where WNP TCs reach their peak intensity. In this case, the migration was consistently found in the data from each regional data source. The migration appears to be related to systematic decadal changes in regional PI and vertical wind shear and is occurring at roughly the same rate as the independently observed expansion of the tropics. $^{78}$ Zhao and Held ${ }^{79}$ simulated some poleward migration of TC genesis frequency with climate warming in the North Pacific and North Atlantic Ocean basins.

\section{North Atlantic}

There are clear increasing trends in observed intensities of TCs in the Atlantic basin in the past few decades. ${ }^{80}$ Kossin et al. $^{3}$ note very significant increases since 1982. Holland and Bruyère ${ }^{61}$ also find an upward trend in the proportion of intense hurricanes since 1975 , significant at the $95 \%$ level when compared to their global warming index. Landsea et al. ${ }^{81}$ emphasize the data homogeneity issues that exist in the Atlantic best track data over the past 100 years, but also note that observed increases have occurred in TC activity in the Atlantic since the 1970s. Murakami et al. ${ }^{82}$ find that the recent increase in TC genesis number in the Atlantic is the primary driver of the increase in aggregate activity measures such as the ACE or PDI. However, the Atlantic basin is noted for having significant multidecadal variability in TC activity levels. The basin was characterized by a more active period from the mid-1870s to the late 1890 s as well as the mid-1940s to the late 1960s. These periods may have had levels of activity similar to what has been observed since the mid-1990s. ${ }^{83}$ Crucial to this analysis has been the construction of more homogeneous datasets over this longer period of time. ${ }^{81}$ Analysis of these suggests a general lack of long-term trends in this basin for both total numbers of TCs and for hurricanes only, as well as for landfalling hurricanes since $1900 .^{2,84}$

Causes for these trends are summarized in the latest Intergovernmental Panel on Climate Change (IPCC) report (AR5), which provided a synthesis of the relationship between climate and TCs, ${ }^{85}$ with particular emphasis on the North Atlantic basin. Confidence has now increased to 'medium' that in the Atlantic basin, external forcing factors such as anthropogenic greenhouse gases and aerosols are partly responsible for the increase in TC formation since the comparatively quiescent 1970s-1980s. In particular, the influence of atmospheric aerosols 
appears to be important in producing the quiescent period in Atlantic TC activity (from about the late 1960s to the early 1990s). ${ }^{18,23,86-89}$ An additional component of this variability is likely driven by fluctuations in the strength of the Atlantic thermohaline circulation that drive changes in SST patterns in the Atlantic Main Development Region. ${ }^{90-92}$ In the Atlantic, observed multidecadal variability of the ocean and atmosphere has been attributed to natural internal variability via meridional overturning ocean circulation changes ${ }^{93}$ natural external variability caused by volcanic eruptions ${ }^{94}$ and Saharan dust outbreaks, ${ }^{95,96}$ and anthropogenic external forcing via greenhouse gases and sulfate aerosols. ${ }^{207}$ However, the relative contributions of each mechanism to the observed multidecadal variability in the Atlantic are presently an active area of research and debate.

It has also been hypothesized that changes in both frequency and intensity of TCs in the Atlantic basin are related to decreases in tropical tropopause temperatures in that basin. Emanuel et al. ${ }^{97}$ used a TC downscaling technique to show that this cooling has contributed to the estimated change in PI in this basin. It was also noted that the trends in this variable in the NCEP-1 reanalysis ${ }^{98}$ are larger than those from other datasets and so likely overestimate these PI trends. Using a high-resolution model forced by observed SSTs, Vecchi et al. ${ }^{10}$ showed that strong cooling in the tropical tropopause layer seen in the NCEP-1 reanalysis is neither simulated by the model, nor it is evident in other observational estimates. In addition, the simulated TC frequency changes in their model are neither significantly affected by simulated tropical tropopause layer temperature changes, nor do they scale directly with PI, and yet the model is still able to simulate the observed TC trends since 1980. They concluded that the tropical tropopause layer temperature trends in the NCEP-1 Reanalysis are therefore unlikely to be accurate, and likely drive spuriously positive TC and PI trends, along with an inflated connection between absolute surface temperature warming and TC activity increases. A recent study by Kossin, ${ }^{11}$ which uses TCs to more directly sample global upper tropospheric temperatures, lends some support to this claim.

Other TC-related datasets have been analyzed for trends in this basin. Using tide gage data, Grinsted et al. ${ }^{99}$ conclude that there is a significant positive trend in eastern United States in storm surge incidence from 1923 to 2008 . Peduzzi et al. ${ }^{100}$ note that demographic pressures over the next 20 years will exacerbate the risk of TC damage, due to increased exposure in the increasingly densely populated coastal regions.

\section{North Indian}

During the period 1961-2008, several studies find substantial decreasing trends in TC activity in the Bay of Bengal and Arabian Sea, particular during the monsoon season. ${ }^{101-103}$ In contrast, Singh ${ }^{67}$ found a marked increasing trend in the most intense TCs in recent decades. Holland and Bruyère ${ }^{61}$ also found a very large increasing trend in the proportion of intense hurricanes in this region since 1975. This was shown to be consistent with global warming trends at the $95 \%$ significance level. Geetha and Balachandran ${ }^{104}$ have studied the decadal variations in the translational speeds of cyclonic disturbances (CDs) over the North Indian Ocean over the period 1961-2010 and have noted that during the most recent decade, the most probable speeds of CDs have increased over the Bay of Bengal, but have decreased over the Arabian Sea.

There are substantial concerns about inhomogeneity due to changes in analysis and observing methods in this basin. For example, prior to the introduction of Meteosat-5 geostationary satellite imagery in 1998, viewing angles in the North Indian Ocean were quite oblique, making identification of the strongest storms quite challenging. ${ }^{3}$

In the adjacent Arabian Sea region, Evan et al. ${ }^{105}$ linked reduced wind shear to the recent observed increase in the number of very intense storms in that region, including the five very severe cyclones that have occurred since 1998. The fundamental cause of this proposed linkage is not yet certain, however. ${ }^{105-107}$

Demographic changes in coastal regions of this basin are also driving changes in TC impacts. Raghaven and Rajesh ${ }^{108}$ examined cyclone landfalls in Andhra Pradesh, India and found a marked increase in impacts, which they attributed to changing economic circumstances and coastal development.

\section{South Indian, South Pacific, and Northeast Pacific}

Callaghan and Power ${ }^{109}$ find a statistically significant decrease in eastern Australia land-falling TCs since the late 19th century, although Hartmann et al. ${ }^{110}$ note that after including 2010/2011 season data, this trend becomes nonsignificant (i.e., a trend of zero lies just inside the $90 \%$ confidence interval). Holland and Bruyère $^{61}$ analyzed the South Indian and western South Pacific regions separately and found an increasing trend in the proportion of intense hurricanes that was significantly related to global warming at the 99\% level. However, the South Indian Ocean basin had the same oblique viewing angle 
issues that characterized the North Indian Ocean ${ }^{3}$ which could partially explain the trend found in that region.

In contrast, Kuleshov et al. ${ }^{111}$ analyzed a compiled Southern Hemisphere best track data archive from 1981. They found no trends in the total numbers of TCs nor in numbers of TCs with central pressures of $970 \mathrm{hPa}$ and lower in the Southern Indian Ocean and the South Pacific Ocean (such TCs being called 'severe' in the Southern Hemisphere). Positive trends in the numbers of TCs with central pressures of less than $945 \mathrm{hPa}$ in the Southern Indian Ocean are significant but appear to be influenced to some extent by changes in data quality. Malan et al. ${ }^{112}$ reported an increased occurrence of severe storm days (category 3 or higher) in the Southwest Indian Ocean since the 1990s associated with the increase in TC heat potential, although total cyclone numbers decreased. In the Australian region, Kuleshov et al. ${ }^{111}$ found no significant trends in the total number of TCs, or in the proportion of the most intense TCs. While this conclusion of Kuleshov et al. is different from that of Holland and Bruyère, slight differences in the methodologies between these two studies may account for this difference.

For the northeast Pacific, studies that have examined trends in this region as part of global trend analysis have found no significant trends in intense TCs. ${ }^{62,113}$ Interdecadal variability in landfalling storms on the Pacific coast of Mexico is substantial and appears to be modulated by the Pacific Decadal Oscillation. ${ }^{114-116}$

\section{ENSO, TCs, and Climate Change}

TC incidence in various formation basins is strongly tied to ENSO variations. ${ }^{117-122}$ Thus, any substantial change in the behavior of ENSO in a warmer world would cause substantial accompanying changes in TC formation regions and tracks. Current high-resolution climate models simulate aspects of the relationship between ENSO and TCs well. ${ }^{20,123-127}$ Nevertheless, Christensen et al. ${ }^{128}$ concluded that at present there was still low confidence in projected changes of the intensity and spatial pattern of ENSO in a changed climate, and thus similarly low confidence in future changes in TC formation regions due to changes in ENSO.

\section{Relationships between TC Formation and Climate}

Understanding the fundamental links between climate and TC is vital to improving the confidence of our future projections of TCs. At present, there is no climate theory of TC formation, in the sense that the number of TCs likely to be produced in a particular climate can be confidently calculated. Links between what appears to be the two-stage process of TC formation (organization followed by intensification) and climate are not well understood. Recent results have strengthened the evidence that TC numbers appear to be tied to changes in the mean vertical circulation in the tropics. ${ }^{43,79,129,130}$ In addition, several results indicate the importance of mid-tropospheric moisture deficit in TC formation. ${ }^{5,131}$ Nevertheless, care needs to be taken to differentiate between the important role of mid-level moisture in the immediate environment of the TC, and the impact of climatological mid-level moisture on broad TC formations. Bruyère et al. ${ }^{132}$ found that climatological mid-level moisture variations were slightly negatively related to interannual variations in TC frequency for the North Atlantic. Based on this analysis, humidity appears to be a threshold parameter for interannual TC formation.

A number of GCM experiments have shown statistical links between climatological upward mass flux and TC formation. Using idealized climate experiments, Held and $\mathrm{Zhao}^{43}$ and Sugi et al. ${ }^{129}$ showed that both the $\mathrm{CO}_{2}$ increase and SST increase contribute about equally to the reduction of future upward mass flux, which they suggested could lead to a reduction of TC frequency. The more recent US CLIVAR Hurricane Working Group experiments, where SST and $\mathrm{CO}_{2}$ values were also changed separately to understand their effects, also reached similar conclusions. ${ }^{130,133}$ In these experiments, it should be noted that the saturation moisture deficit does not change in the $\mathrm{CO}_{2}$ increase (without SST increase) experiments, and thus it does not explain the reduction of TC frequency in the $\mathrm{CO}_{2}$ increase experiments in these models. ${ }^{130} \mathrm{~A}$ remaining issue is why the decrease of mean upward mass flux leads to a reduction of TC frequency. A recent study by Satoh and Yamada ${ }^{134}$ proposed that an average TC intensity increase combined with a climate-related constraint for the total TC mass flux leads to the reduction of TC numbers.

Recent advances have also been made in the formulation of statistical relationships between climate and TC formation, the so-called genesis potential indices (GPIs). ${ }^{135}$ Numerous issues remain regarding their application. Bruyère et al. ${ }^{132}$ showed that care needs to be taken with the area selected for application of the genesis parameter. For the North Atlantic, application of these parameters to the Main Development Region east of the Lesser Antilles 
enables good reproduction of observed variability and trends, but using the whole basin substantially degrades this. They also found that PI and vertical shear are good predictors, especially when used together. Low-level vorticity makes no contribution and mid-level moisture is weakly negatively related to cyclone formation frequency. These findings are in agreement with earlier studies by Tippett et al. ${ }^{136}$ However, the lack of mid-level moisture signal is not supported by Emanuel and Nolan ${ }^{137}$ and Emanuel. ${ }^{138}$ Furthermore, by modifying existing GPIs by making the humidity predictor the column saturation deficit and by using PI as the thermodynamic predictor, decreases in future TC formation simulated by the HIRAM model $^{17}$ can be captured $^{139}$ (Figure 2). Peng et al. ${ }^{140}$ also investigated environmental parameters controlling TC genesis in the North Atlantic using observations. They concluded that thermodynamic variables were more important controlling parameters than dynamic
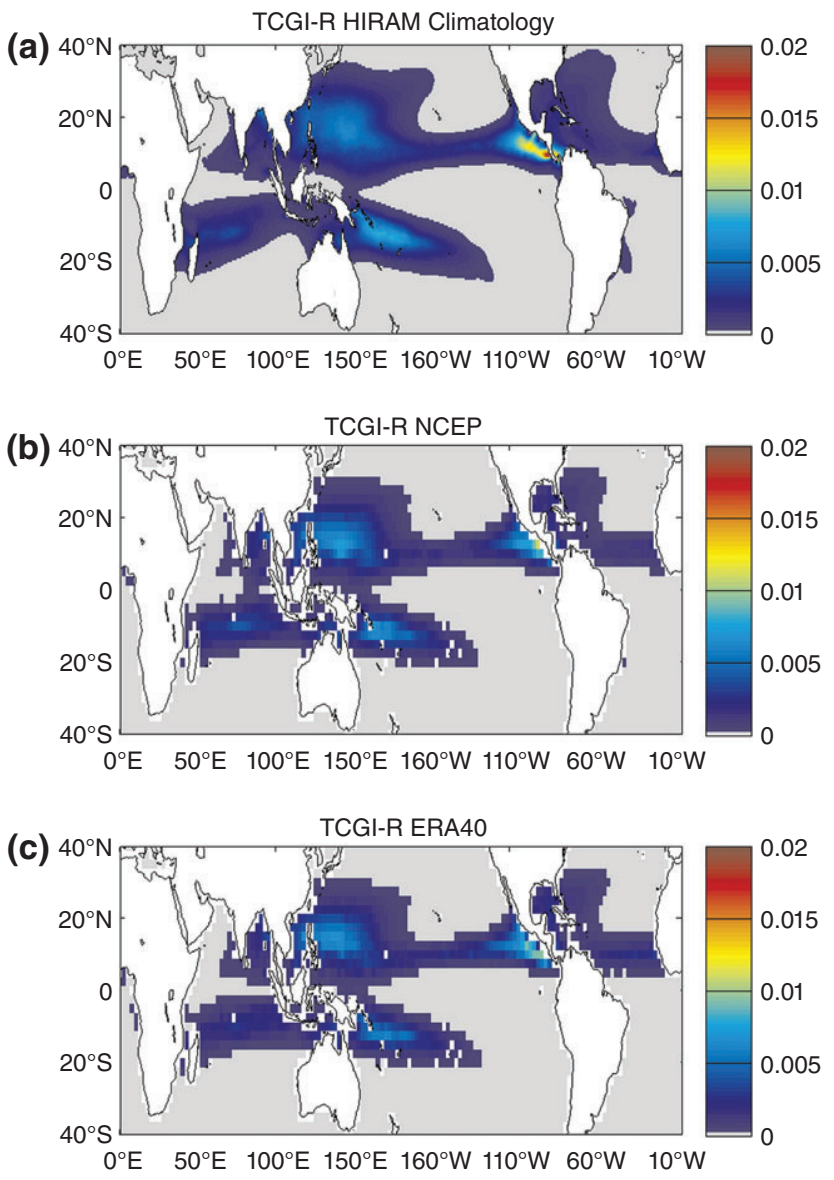

FIGURE 2 | Climatology of a revised genesis index per year for (a) HiRAM climatology, (b) NCEP reanalysis, and (c) ERA-40. (Reprinted with permission from Ref. 139 Copyright 2014 American Meteorological Society) variables for TC genesis in the North Atlantic. Examining the eastern and western Atlantic separately $(40 \mathrm{~W}$ separation line), they concluded that $925-400 \mathrm{hPa}$ water vapor content was the most important controlling parameter for TC genesis for both regions. Other important parameters included SST and $700 \mathrm{hPa}$ vorticity in the east and, and horizontal shear and divergence in the west Atlantic.

Given the current uncertainties regarding the precise formulation of GPIs, further work is needed on the contributions of various environmental parameters to TC formation.

\section{Theoretical Relationships between Climate and Intensity}

The now well-established thermodynamic theory of TC maximum $\mathrm{PI}^{141,142}$ continues to be investigated and refined. In addition, there has been considerable work done since 2010 analyzing the 'relative SST' argument, namely that TC characteristics such as PI in a basin can be affected locally by basin SSTs because tropical upper troposphere temperatures tend to follow the global tropical average instead of the basin average. Thus, the relative SST can serve as a useful although not perfect proxy for PI. ${ }^{143}$ Camargo et al. ${ }^{144}$ and Ting et al. ${ }^{145}$ indicate that the decrease in PI in the Atlantic basin caused by aerosol forcing and its increase due to greenhouse gas forcing largely canceled each other, and the sharp increase in the PI in the last 30 years in this region was dominated by multidecadal natural variability. They argue that this is more effective in increasing PI than increases in SST related to climate change. In contrast, the observed increases in both global and basin proportions of intense hurricanes found by Holland and Bruyère ${ }^{61}$ were all related to global changes, which models indicated were arising from anthropogenic effects, and they could find no natural multidecadal trend in the models that could explain this behavior. Projections are uncertain on whether relative SST (or tropical storm frequency) in the Atlantic basin will increase during the 21st century under GHG forcing. ${ }^{23,146,147}$ In addition, the role of tropopause temperature trends in observed changes in the PI appears unresolved, ${ }^{10,97,148,149}$ thus reducing our confidence in future projections of this relationship.

\section{PROJECTION OF FUTURE TC CLIMATOLOGY}

Climate models are the main tools for the projection of the future effect of anthropogenic warming, but for TCs they generally suffer from inadequate 
horizontal resolution. The horizontal resolutions of climate models of TCs range from $\sim 100$ to $300 \mathrm{~km}$ for the CMIP5 models down to $\sim 10-50 \mathrm{~km}$ for the new generation of high-resolution models. Christensen et al. ${ }^{128}$ provide a synthesis of global and regional projections of future TC climatology by 2081-2100 relative to 2000-2019. Globally, their consensus projection is for decreases in TC numbers by approximately $5-30 \%$, increases in the frequency of categories 4 and 5 storms by $0-25 \%$, an increase of $0-5 \%$ in typical lifetime maximum intensity, and increases in TC rainfall rate by $5-20 \%$ (Figure 3 ).

\section{TC Numbers and Occurrence}

A number of new, high-resolution simulations of the generation of TCs by climate models have been performed in recent years. Several models are now able to give reasonable simulations of TC formation in most basins, ${ }^{17,147,150,151}$ although simulating formation in the Atlantic remains a challenge. ${ }^{152,153}$ The most recent simulations indicate an improved ability to simulate Atlantic TC formation. ${ }^{154}$ Most models (with one or two exceptions) continue to simulate fewer TCs in a warmer world, particularly in the Southern Hemisphere. ${ }^{155,156}$ For the direct detection of TCs in CMIP5 model projections, there are large biases in most models, due to their relatively low horizontal resolution. ${ }^{157}$ If we exclude models that have an extremely poor TC climatology in the present climate, most models projections are for a reduction of future global TC frequency. Using different detection method, Camargo ${ }^{158}$ did not obtain a robust response in future changes in CMIP5-coupled models global TC frequency in the future warmer climate. A few showed an increase, others showed no change, and several showed a decrease in TC global frequency. However, a few models that were analyzed in common by both Tory et al. ${ }^{159}$ and Camargo ${ }^{158}$ were in agreement in having significant frequency decreases. ${ }^{156}$ Murakami $^{157}$ also investigated the influence of model biases on future TC projections using an empirical statistical analysis.

Murakami et al. ${ }^{19}$ present results from four experiments with 20 and $60 \mathrm{~km}$ resolution MRIAGCMs (Figure 4), while Murakami et al. ${ }^{160}$ present results of 12 simulations with $60 \mathrm{~km}$ resolution MRIAGCMs (Figure 5). With these experiments, the number of experiments for global TC frequency change increases from 19 in the study by Knutson et al. ${ }^{28}$ (their Table S1) to 35 in the study by Christensen et al. ${ }^{128}$ (their Table 14.SM.4a). These newer results also indicate decreased numbers of TCs in a warmer world. One important point in
Murakami et al. ${ }^{19}$ is that the TC intensities simulated by the $20 \mathrm{~km}$ resolution models with a different convection scheme are significantly different. The MRIAGCM 3.2 (the new version of the model) with a new convection scheme simulates very intense TCs, comparable to observed intensities, while MRIAGCM 3.1 (old version) significantly underestimates the TC intensity, indicating that the simulated TC intensity response depends not only on the resolution but also depends significantly on the convection scheme.

Murakami et al. ${ }^{160}$ further examined systematically the impact of model physics and SST change patterns on global and regional TC frequency changes. Murakami et al. ${ }^{19,160}$ indicated that there were three major source of uncertainty in the TC frequency change projections: (1) resolution, (2) physics (convection scheme), and (3) SST pattern change. The response of TCs to increased greenhouse gases depends on resolution, with finer-resolution models showing stronger decreases in TC numbers. ${ }^{150,161,162}$

An exception to the general projection of decreases in future TC numbers is Emanuel, ${ }^{163}$ in which TC numbers are projected to increase. In the method used in this study, a downscaling technique is applied in which a constant 'seeding' rate for tropical disturbances is imposed under different climate conditions, and the 'seeds' that develop into TCs are then counted. There is an indication that the seeding rate in at least one climate model decreases with climate warming (Ming Zhao, personal communication, 2015).

There remains considerable disagreement between models regarding projections for individual basins, however. ${ }^{156,158}$ Regionally, an important new result is the possibility of an increase in TC numbers in the region near Hawaii. ${ }^{164,165}$ Modeling studies also suggest changes in future TC activity for the WNP basin. More models project decreases than increases in tropical storm frequency. Most studies project an increase in the TC intensity and increases in TC precipitation rates. ${ }^{73}$ In the North Indian Ocean, Murakami et al. ${ }^{166}$ use a high-resolution ensemble to show a $46 \%$ increase in TC numbers over the Arabian Sea and a 31\% decrease over the Bay of Bengal by the late 21st century.

Theoretical techniques have been applied in an effort to increase our confidence in regional projections. The influences of vertical wind shear, entropy deficit and PI are combined by Tang and Emanuel ${ }^{142}$ in a 'ventilation' index. In Tang and Camargo, ${ }^{167}$ this is used as a metric to assess possible changes in TC frequency in CMIP5 models. They showed that by the end of the 21st century there is an increase in 

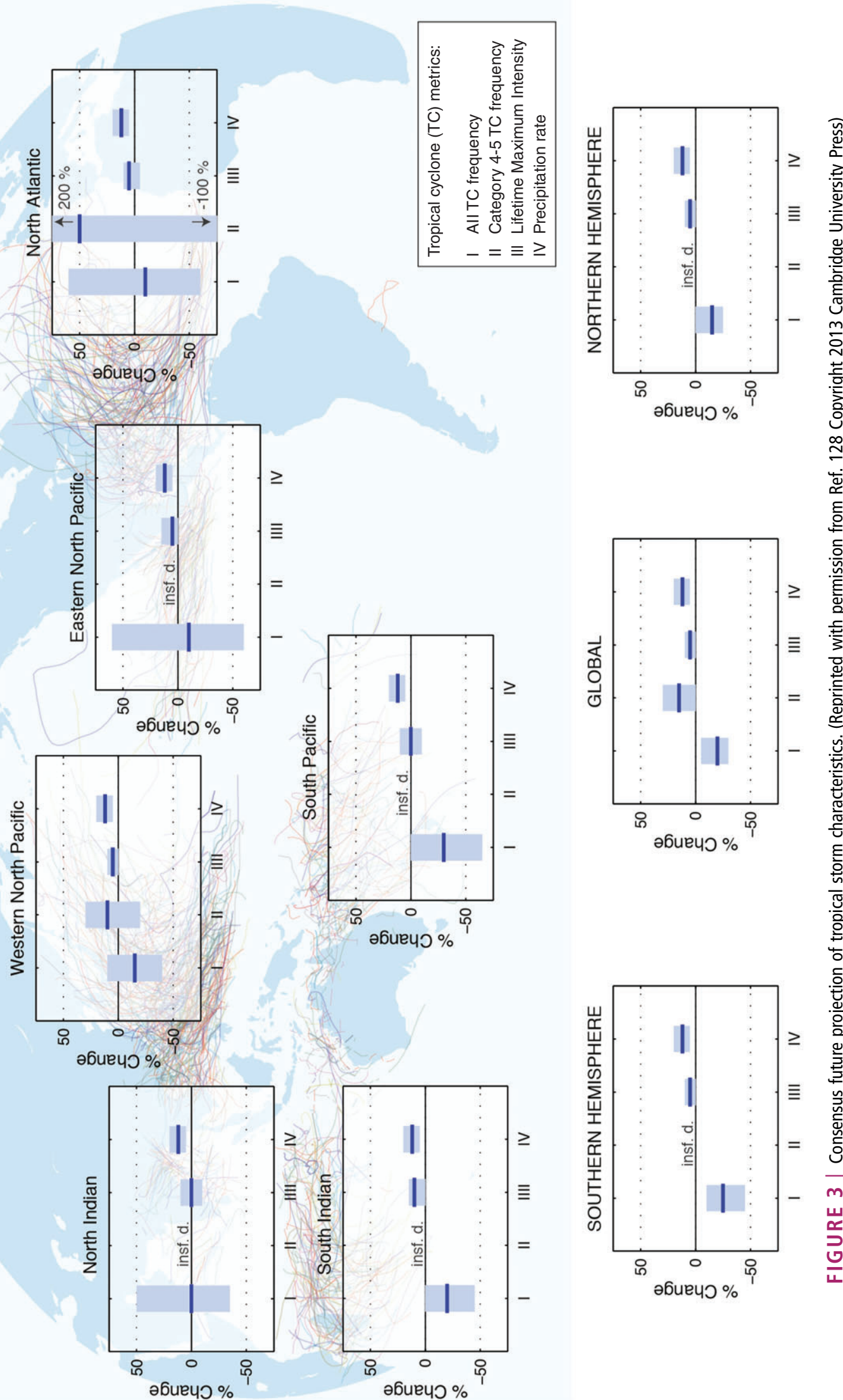

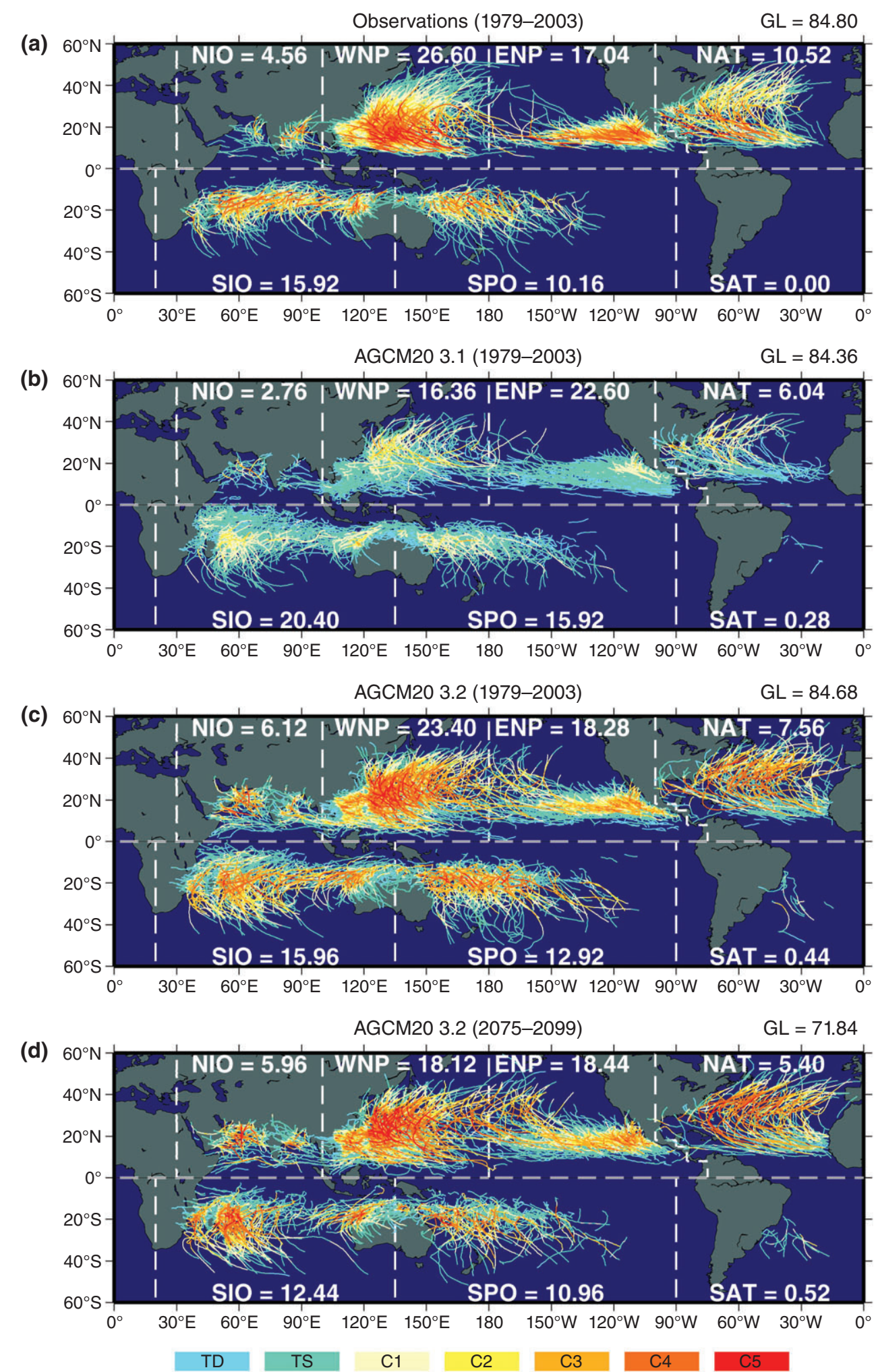

FIG URE 4 | Global distribution of TC tracks during all seasons from 1979 to 2003 for (a) observations, (b) and (c), two current climate TC simulations, and (d) the global warming projection using the same GCM as for (c). The numbers for each basin show the annual mean number of TCs. TC tracks are colored according to the intensities of the TCs as categorized by the Saffir-Simpson hurricane wind scale (e.g., tropical depression [TD], tropical storms [TSs], and TC category C1-C5). (Reprinted with permission from Ref. 19 Copyright 2012 American Meteorological Society) 
GL

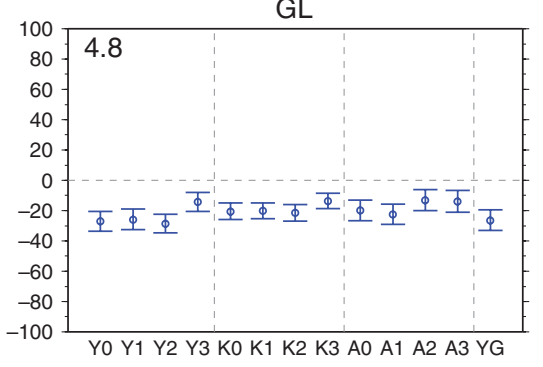

$\mathrm{NIO}$
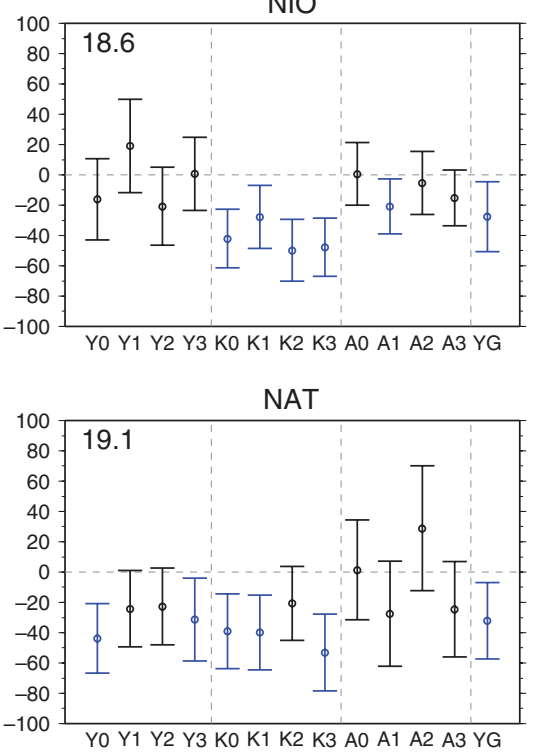

$\mathrm{NH}$

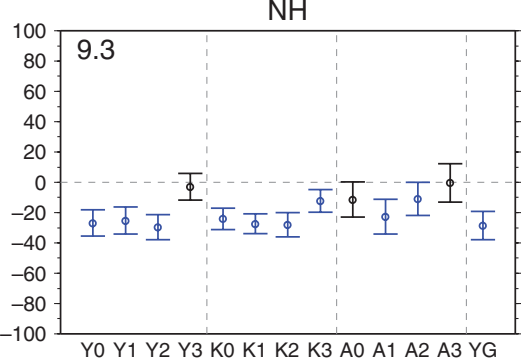

WNP

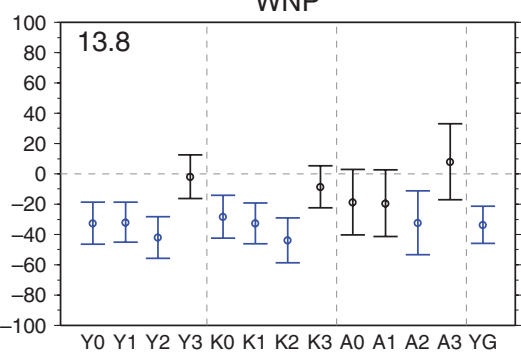

SIO

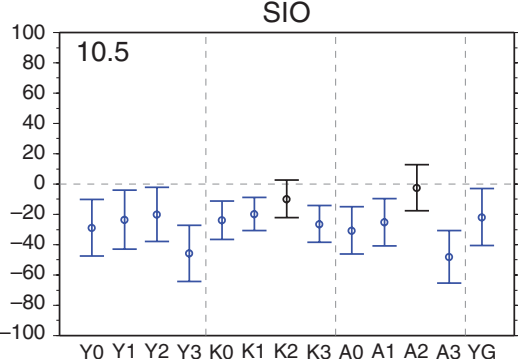

$\mathrm{SH}$

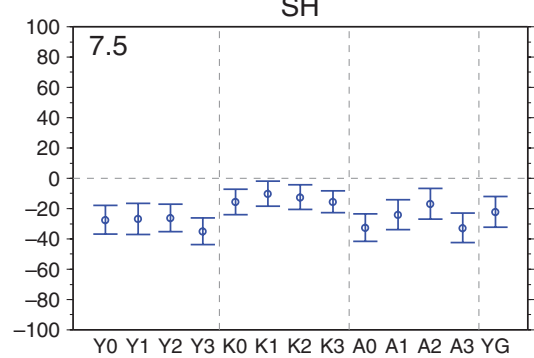

ENP

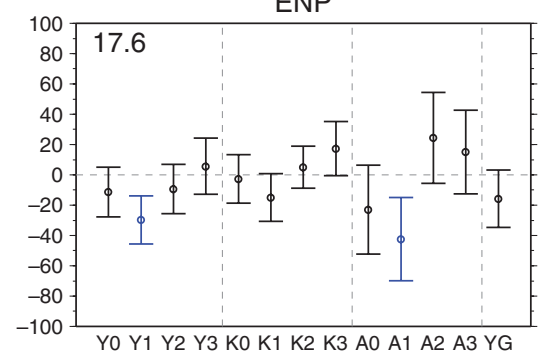

SPO

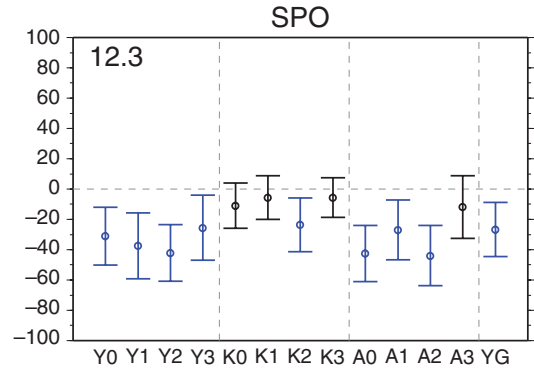

FIGURE 5 | Fractional future changes (\%) in TC genesis number for each basin for a group of ensemble experiments, for three different convection schemes and four different future SST patterns. The error bars indicate $90 \%$ confidence intervals. Blue bars indicate that projected future changes that are statistically significant at $90 \%$ level according to the two-sided Student's $t$-test. The number in the top left corner of each panel shows the standard deviation of twelve ensemble experiments (YG experiment is not included). (Reprinted with permission from Ref. 19 Copyright 2012 Springer)

the seasonal ventilation index, implying less favorable conditions for TC genesis or rapid intensification in the majority of the TC basins, with the exception of the North Indian Ocean. Basin changes in the index are well correlated with changes in TC frequency and intensification in the models.

Another important question is whether the typical regions of occurrence and resulting impacts of TCs in today's climate might change in a warmer world. Evans and Waters ${ }^{168}$ examined results from coupled models to show that the threshold temperature for onset of deep convection-often associated with regions prone to tropical cyclogenesis-is likely to increase in a warmer world. A similar result has been obtained from observations for the amount of warming that has occurred so far. ${ }^{169,170}$ One implication of this result may be little change in future regions of cyclogenesis, as an increase in the future threshold temperature of deep convection is also accompanied by a general increase in SSTs. However, if a substantial change in the threshold temperature for TC formation will occur in the future, it has not been observed yet: Dare and $\mathrm{McBride}{ }^{45}$ examined all global individual TC formation events from 1981 to 2008. Dividing the 27-year dataset into an earlier versus a later 13.5-year period, positive but small changes $\left(+0.20^{\circ} \mathrm{C}\right)$ occur in the mean formation temperature.

TC occurrence can be affected by changes in typical TC tracks. Colbert et al. ${ }^{171}$ used a statisticaldynamical modeling approach to estimate future changes in TC tracks in the North Atlantic, finding a decrease in westward tracks and in increase in recurving tracks. This would imply a decrease in landfall in the Caribbean and North America independent of overall changes in activity. Murakami and Wang ${ }^{172}$ reported that TC tracks would shift eastward in the North Atlantic in a warmer climate. In the WNP, Wang et al. $^{173}$ used singular value decomposition 
(SVD) analysis and found that the observed TC track changes are linked to the leading SVD mode of global SST warming and to associated changes in large-scale steering flows. They suggested that future changes in these steering flows using the SVD mode as simulated using five CMIP3 models implied that the currently observed track changes in this region, with more storms over subtropical East Asia and less over the South China Sea, may persist until at least 2040. In another study, Murakami et al. ${ }^{174}$ used a $20-\mathrm{km}$ mesh global model to simulate possible future changes in TC activity over the WNP. They noted an eastward shift in the positions of the prevailing northward recurving TC tracks during the peak TC season (July-October) for 2075-2099, resulting in a significant reduction in the number of TCs approaching coastal regions of Southeast Asia. Yokoi and Takayabu $^{175}$ also performed future projections of the regional TC passage frequency over the WNP by using seven CMIP3 GCMs. The models project increases in the TC passage frequency over the tropical central North Pacific and decreases in regions to the west and northwest, including East Asian countries. Their analysis reveals that the gross horizontal contrast in the passage frequency changes is caused by a projected eastward shift of the main TC development region, probably caused by the pattern of projected SST changes, which is uncertain. Moreover, the likely track changes would decrease the passage frequency over the Korean peninsula, Indochina peninsula and western Japan, but increase that over eastern Japan and the eastern coast of central China. A consistent projected increase in TC occurrence in the Central Pacific is also reported in a few studies. ${ }^{164,165}$

\section{TC Intensity}

A notable change in the capability of climate models of TCs in the last few years is that more high resolution climate simulations can now simulate reasonably well the observed intensity distribution of TCs. ${ }^{19-21,147,176-178}$ These high-resolution models typically predict an increase in the frequency of the most intense TCs. Ideally, although, even higher resolutions would be preferable for the best representation of the TC intensity response. ${ }^{179,180}$ Along these lines, the sensitivity of limiting hurricane intensity (a statistical analog of maximum PI) has recently been estimated to be about $8 \mathrm{~ms}^{-1} \mathrm{~K}^{-1}$ in the Atlantic basin, which is similar to the estimated sensitivity to patterns of SST change of PI computed across a suite of coupled GCMs, ${ }^{169}$ but this sensitivity is not reached for simulated TCs in some recent high-resolution climate models, ${ }^{181,182}$ likely due to resolution issues. Statistical downscaling of the GCM-simulated intensity distribution is also demonstrated to be useful for understanding present-day intensity variability and future change. ${ }^{22}$

For societal impacts, Christensen et al. ${ }^{128}$ note that the number of very strong cyclones is usually more important than a measure such as mean intensity. Several studies ${ }^{50-52}$ provide evidence that predicting societal impacts also requires explicit inclusion of hurricane size and translation speed changes. Note that physical factors like storm size and intensity are difficult for global models to simulate directly unless very fine resolution is used, yet these are factors that are important for societal impacts of TCs, which are largely dominated by the rarer, high-intensity storms.

\section{Air-Sea Interaction}

The exchange of energy between the ocean and the atmosphere is the fundamental reason why TCs intensify, ${ }^{181,182}$ so capturing this process in model simulations of TCs is important. Because of the very significant computational cost of running highresolution coupled ocean-atmosphere GCMs, most very high-resolution simulations of the effect of climate change on TCs have been performed using the time-slice method, whereby simulated SSTs from a coarser-resolution model are used as a boundary condition for the simulation of a finer-resolution atmosphere-only climate model. While this technique is far more economical in computer time than using a fully coupled ocean atmosphere GCM to perform the same projection, the lack of full air-sea interaction in the time-slice experiments has raised questions about their realism, especially for simulating intense TCs where air-sea energy exchanges are strong. However, the limited number of high-resolution coupled model simulations that have been performed to date obtain similar results to the atmosphere-only GCMs. Kim et al., ${ }^{183}$ using the GFDL CM2.5 coupled model at a horizontal atmospheric resolution of about $50 \mathrm{~km}$, note a strong link in their model simulations between decreases in TC occurrence and decreases in upward mid-tropospheric vertical velocity in TC formation regions, similar to that found in the atmosphere-only models. In addition, like the atmosphere-only models, they also simulate too few storms in the Atlantic. The response to increased $\mathrm{CO}_{2}$ in their model is a substantial decrease in TC numbers in almost all basins, and an increase in average TC intensities by about $3 \%$, again similar to results from atmosphere-only models. Nevertheless, a 
resolution of $50 \mathrm{~km}$ is still coarse compared to the resolution required to simulate reliably the TC intensity distribution.

In addition to the effect of climate on TCs, TCs themselves also appear to have some effect on the global climate. State-of-the-art fully coupled GCMs are able to represent the TC interaction with the ocean and TC activity (given the aforementioned under-simulation of TC intensities) seems to significantly impact the ocean heat transport (OHT) within the tropical belt, on short time scales, but no significant changes appear to have occurred over the past half-century. ${ }^{184}$ The role of TCs in the OHT has been quantified but the range of estimates is large and the TC-induced transport response differs from study to study. ${ }^{185}$

\section{TC Rainfall and Other Impacts}

Christensen et al. ${ }^{128}$ note that the increase in rainfall rates associated with TCs is a common response of numerical models under greenhouse warming. ${ }^{147,183,186,187}$ Projected increases in TC rainfall typically range from 5 to $20 \%$, although results can vary somewhat between different TC basins. ${ }^{178}$ The quantitative changes may also depend on the details of the TC precipitation metric chosen. Nonetheless, an increase in storm-relative rainfall rates from composite storms in a warmer climate is one of the more confident predictions of the effects of future climate on TCs.

There have not yet been any detected global trends in TC rainfall rates. ${ }^{188}$ Chang et al. ${ }^{52}$ examined a multidecadal trend in rainfall from TCs affecting Taiwan. They found that the observed increases arose from relatively weaker typhoons and could largely be attributed to an increase in slow-moving systems. They could not find a mechanism that attributed this trend to anthropogenic climate change.

The most important impact of TCs in coastal regions is storm surge. Increases in storm surges due to TCs may be caused by a combination of sea level rise and increases in TC wind speeds. ${ }^{189}$ Woodruff et al. ${ }^{190}$ reviewed this topic, noting that projections of sea level rise are more confident than projections of changes in TCs. In some locations, sea level rise may dominate the changes in storm surge climatology. ${ }^{191}$ From the point of view of the prediction of societal impacts, this outcome actually makes future predictions of storm surge incidence more confident, due to the higher confidence in future sea level rise projections. All else being equal, sea level rise will cause increases in the total flood level associated with a given return period. Particularly for shorter return periods, it is likely that this effect will dominate over changes in the storm climate. The total flood levels associated with return periods on the order of 100 years or less, e.g., are very likely to increase, according to calculations to date based on several climate models. At longer return periods, changes in the frequencies and intensities of TCs play a larger role, and increase the uncertainty in the flood levels for those more extreme events. ${ }^{189}$

Tebaldi et al. ${ }^{192}$ present projections of storm surges along the U.S. coast based on historical tide gage trends, which generally also include vertical land movement effects as well as sea level effects. They did not incorporate storm change effects. By 2050, today's 100-year events become 'decadalreturn-time' events for about a third of their study gages. They noted that 'Gulf locations appear in least danger of a rapid shift (in extreme return levels/periods), despite rapid relative sea level rise, due to the high amplitudes of historical storm extremes, which render the relative effect of sea level rise small.'

In summary, model studies indicate that sea level rise contributes toward increased surge risk, although the full change in risk is influenced by storm climate changes as well, particularly for rarer, more extreme surge events.

Done et al. ${ }^{51}$ examined potential future changes in North Atlantic hurricane impacts on offshore energy structures in the Gulf of Mexico. Using simulations of hurricane case studies, they found a future increase in the frequency of most intense hurricanes, but that the cyclones became smaller and moved faster. The net result is a predicted reduction in hurricane impacts on offshore energy structures in the Gulf.

\section{TC Detection Issues}

Ideally, there should be no uncertainty introduced by the method used to detect TCs in a climate model simulation. In practice, climate model studies use a wide range of TC tracking and detection schemes, ${ }^{193}$ but no detection technique is perfect. ${ }^{153,159}$ Traditional direct detection methods use (1) structural criteria to ensure a disturbance resembles a TC and (2) a wind speed threshold to determine if the disturbance is sufficiently intense to be considered a TC.

Some allowance needs to be made when setting these criteria for that fact that TC-like circulations in climate models are not well resolved, which introduces an element of subjectivity to the definition of what actually is a 'climate model TC.' Various attempts have been made to reduce this subjectivity, 
including the development of a relationship for wind speed thresholds as a function of grid resolution, ${ }^{194}$ and the development of alternative direct detection methodologies. ${ }^{153,159,195}$ The Camargo and Zebiak ${ }^{158}$ method applies statistically determined thresholds to the wind speed and two structural criteria (vorticity and warm-core), so that extreme circulations, as determined by the variability within the TC basin of interest, are declared TCs. The Tory et al. ${ }^{152}$ detection method attempts to identify the large-scale environment in which TCs form, and if this favorable environment persists for $48 \mathrm{~h}$, a TC is declared. The method is based on the Okubo-Weiss-Zeta Parameter (OWZP), which identifies the existence of large-scale regions of nearsolid body rotation in the low- and mid-troposphere. Where these coincide with enhanced relative humidity and weak vertical wind shear, the environment is considered favorable for TC development.

Each method has strengths and weaknesses and indeed when applied to the same model they can produce somewhat different results. ${ }^{156}$ Horn et al. ${ }^{193}$ find some sensitivity to the choice of TC detection scheme when applied to the results from various perturbation climate experiments, although once minor differences between the schemes were removed, the results of the perturbation experiments became more similar. It is also noted that not all disturbances in the tropics with low-level wind speeds greater than $17 \mathrm{~ms}^{-1}$ are TCs (e.g., monsoon gyres ${ }^{196}$ ), so there will continue to be a need for a reliable TC detection method for the analysis of climate model output. Until climate models can be run at a fine enough resolution to resolve adequately inner-core TC structure, alternative methodologies such as the Camargo and Zebiak and Tory et al. detectors can offer valuable insight into detection uncertainty when used in parallel with the traditional direct detectors.

\section{RESEARCH TOPICS FOR THE FUTURE}

\section{Detection Methods As a Source of Uncertainty}

The various methods used to detect TCs in climate models can be viewed as a form of modeling uncertainty. Given that current detection techniques can deliver different results when analyzing the same climate modeling system (as noted above), there could be value in analyzing subjectively the circulations that each detector detects. For example, does the detector that systematically detects fewer TCs only identify the strongest circulations? Such knowledge will better inform projection results. This still implies a need for standardized detection techniques, although it is noted that this outcome may need to wait until climate models can routinely simulate well the intense inner-core region of TCs. Furthermore, it is expected that the differences among detection methodologies will decrease as the models increase horizontal resolution and the TC activity is better simulated. Having unified detection methods across different resolutions will be important.

\section{Lack of a Climate Theory of TC Formation}

As stated earlier, a theory of any kind that tells us what the probability of TC genesis is for a given large-scale environment is not available at this time. Therefore, historically, there has been a reliance on empirical genesis indices, and more recently, on the new generation of global atmospheric models that have begun to produce increasingly realistic results for TC climatology. While this recent development is encouraging, confidence in the predictions of these models would be considerably enhanced if they could be compared to the results of a realistic climate theory of TC formation, just as high-resolution model predictions of future increases in maximum TC intensities have been made more confident by a realistic theory of maximum PI.

\section{Confidence in Detection and Attribution of Observed Changes in TCs To Date}

While there has certainly been an increase in TC activity in the Atlantic basin since the 1970s, debate continues over the relative contributions of internal climate variability versus the radiatively forced response. Similarly, debate still continues about trends in the temperatures of the tropical upper troposphere, which are important for evaluating climaterelated changes in TC activity.

Typically, climate models are needed in order to attribute changes in TC activity to a specific cause, such as anthropogenic forcing. For example, to assess whether an observed trend is 'detectable' or unusual compared to trends expected from natural causes alone, a comparison of the trend with the distribution of trends from long simulations of natural variability alone (without anthropogenic forcing) is often used. Models run with and without a given set of forcings (e.g., with and without anthropogenic forcings) can be important tools for assessing causes of an observed change. If an observed change is consistent with that simulated by models that include a given 
set of forcings (e.g., anthropogenic plus natural forcings) and inconsistent with the simulation obtained using only a subset of the forcings (e.g., runs with natural forcings only), this indicates a change which is attributable, according to the models, to anthropogenic forcing. While such procedures have been used for surface temperature changes and other variables, their use for assessing historical TC changes is relatively rare. One example is a modeling study of anthropogenic aerosol forcing of historical Atlantic tropical storm multidecadal variability by Dunstone et al., ${ }^{18}$ although other models differ on how much anthropogenic aerosols have contributed to the observed North Atlantic multidecadal TC variability. ${ }^{23}$ In general, the relative contributions of aerosol forcing and internal climate variability to observed North Atlantic multidecadal SST variability remains a topic of research and discussion. ${ }^{87,88}$

The observed regional shifts in TC activity in the WNP basin in recent decades may have significant implication for landfalling TCs and associated impacts various countries in the WNP. ${ }^{197,198}$ Further studies are required to identify the possible causes and relative contribution of global climate change to these changes. Similarly, while climate models project more precipitation from TCs in the WNP (and globally) in the 21st century, observational studies and model simulations are required to assess the long-term variations of the total and extreme rainfall induced by TCs for different countries in the WNP (and globally) in the past and the 21st century.

There remains considerable work that can be performed in producing more homogeneous datasets of TCs for climate analysis. ${ }^{3,47,58,81}$ The production of datasets that make allowance for undersampling of TC counts in the presatellite era, as pioneered in the Atlantic basin, could be extended to other basins. In particular, reanalysis efforts to create more homogeneous records of landfalling TCs are needed.

It has been inferred from paleotempestology studies that variations in TC activity over centennial time scales have been large, based on studies at a limited number of locations. Reasons for these apparent large centennial-scale TC activity variations are presently unknown.

\section{Impact of Uncertainty in Future Projections of Large-Scale Climate Fields}

One of the reasons that confidence in future regional projections of TCs remains limited is the variation between climate models of projections of mean patterns of change of regional SSTs. Therefore, it remains important to improve climate model simulation in order to reduce uncertainties in the 21 stcentury projections of the mean magnitude and patterns of change of both regional SST patterns and of the vertical structure of the atmosphere (temperature, winds, and moisture), as these differences can lead to large differences in regional TC projections. Additionally, the future changes in climate models such as ENSO and the resulting effects on TC projections are still unclear, given the lack of agreement and poor simulation by many climate models of those climate modes.

In this context, the CMIP5 experiments are important. Analysis of these experiments for changes in TCs has only started ${ }^{156,158,163}$ and more results will need to be produced before a consensus can emerge on the likely effect of the CMIP5 experimental results on TCs.

\section{Correct Simulation of TC Frequency Response in High-Resolution Climate Models}

Even if there were high confidence in future mean large-scale environmental changes, there would still be uncertainties due to the simulated response of TCs in the climate models. Improved theoretical understanding of the relationship between climate and TCs would assist in decreasing existing uncertainties. Model resolutions will soon become high enough for routine comparisons to be made between the smallscale mechanisms of TC formation in models and in observations.

Most genesis indices predict an increase in future TC numbers, while the models predict decreases in TC frequency decreases in most cases. It is not clear whether this is a problem with the formulation of the genesis indices ${ }^{139}$ or that the models are incorrect and so TC frequency will actually increase. $^{163}$

\section{CONCLUSION}

Paleotempestology work has identified large, centennial to millennial scale variations in regional TC incidence, the causes of which are at present not understood. The paleotempestology record needs to be extended both in time and space, and combined with proxy-based and modeling studies to determine the reasons for these variations. Establishing these reasons might assist in the development of a climate theory of TC formation. Analysis of both data and climate simulations may enable to development of 
quantitative constraints on the formation of TCs under various climate conditions. These could then be employed to inform the results of climate model projections.

A number of recent papers have documented global increases in the proportion of very intense cyclones and also of trends in the latitude of maximum TC intensity, consistent with the model projections for future climate. Confidence in these projections continues to increase as simulations improve in quality. It is recommended that further research be undertaken to reduce the uncertainties in the detection of trends in TCs, particularly in the presence of continually improving observational capabilities. This could include (ideally) the extension of aircraft reconnaissance to other regions of the globe. Further improvements of the IBTrACS dataset should be undertaken, especially reanalysis efforts in the WNP basin, where significant differences in intensities between various best track datasets remain.

The recent assessment of Christensen et al. ${ }^{128}$ provided a synthesis of then-available global and regional projections of future TC climatology by 2081-2100 relative to 2000-2019, for a mid-range A1B-like scenario. Globally, the consensus projection was for decreases in TC numbers by approximately $5-30 \%$, increases in the frequency of categories 4 and 5 storms by $0-25 \%$, an increase of a few percent in typical lifetime maximum intensity, and increases in TC rainfall amounts by $5-20 \%$. However, it is noted that there is a large uncertainty in these projections.

One source of uncertainty that has emerged is that somewhat different results can be obtained for model sensitivity experiments if different TC detection methods are used. It is useful to pose the question whether the community should converge on a single method for the detection of TCs in climate models, although this may need to wait until climate models produce improved simulations of inner-core TC dynamics and thus better intensities. In the meantime, the careful comparison and use of more than one detection method is needed for the assessment of climate model simulations.

Climate models will continue to improve, by incorporating improved physics and through increases in typical horizontal resolution. The next challenge for the TC/climate change community is to use climate models to simulate the observed, cloudscale processes leading to TC formation, to ensure that such simulations give realistic depictions of this process. In addition, the climate modeling community should eventually move toward using coupled models capable of more realistic TC simulation. More analysis should be undertaken of existing coupled model experiments, e.g., CMIP5, including possibly the inclusion of a bias correction for intensity. ${ }^{199}$

While the formulation of GPIs continues to be in a state of flux, combining statistical and dynamical approaches to simulate past interannual variability of TC activity has shown considerable promise, and it is recommended that this be expanded to consider new approaches.

Against the background of global climate change and sea level rise, it will be important to have quantitative assessments on the potential risk of TC induced storm surge and flooding to densely populated coastal cities/river delta regions in the coming decades and century. A more comprehensive database should be established on casualties and economic loss for monitoring any long-term trends of TC impacts in the different TC basins.

\section{ACKNOWLEDGMENTS}

This article is a revised and extended version of section 5.1 of the workshop report for the 8th International Workshop on Tropical Cyclones, held at Jeju, Korea, 2-10 December 2014. The authors would like to thank Kerry Emanuel, Kevin Tory, and members of the Hurricane Working Group of U.S. CLIVAR and the WMO Expert Team on Climate Change Impacts on Tropical Cyclones for valuable comments on this manuscript.

\section{REFERENCES}

1. Knapp KR, Kruk MC, Levinson DH, Diamond HJ, Neumann CJ. The international best track archive for climate stewardship (IBTrACS) unifying tropical cyclone data. Bull Am Meteorol Soc 2010, 91:363-376.
2. Vecchi GA, Knutson TR. Estimating annual numbers of Atlantic Hurricanes missing from the HURDAT database (1878-1965) using ship track density. J Clim 2011, 24:1736-1746. doi:10.1175/ 2010JCLI3810.1. 
3. Kossin JP, Olander TL, Knapp KR. Trend analysis with a new global record of tropical cyclone intensity. J Clim 2013, 26:9960-9976.

4. Knutson TR, Sirutis JJ, Garner ST, Held IM, Tuleya RE. Simulation of the recent multidecadal increase of Atlantic hurricane activity using an 18-km-grid regional model. Bull Am Meteorol Soc 2008, 88:1549-1565. doi:10.1175/BAMS-88-10-1549.

5. Emanuel K, Sundararajan R, Williams J. Hurricanes and global warming: results from downscaling IPCC AR4 simulations. Bull Am Meteorol Soc 2008, 89:347-367.

6. Kistler R, Collins W, Saha S, White G, Woollen J, Kalnay E, Chelliah M, Ebisuzaki W, Kanamitsu M, Kousky V, et al. The NCEP-NCAR 50-year reanalysis: monthly means CD-ROM and documentation. Bull Am Meteorol Soc 2001, 82:247-267.

7. Saha S, Moorthi S, Pan H-L, Wu X, Wang J, Nadiga S, Tripp P, Kistler R, Woollen J, Behringer D, et al. The NCEP climate forecast system reanalysis. Bull Am Meteorol Soc 2010, 91:1015-1057.

8. Dee DP, Uppala SM, Simmons AJ, Perrisford P, Poli P, Kobayashi S, Andrae U, Balmaseda MA, Balsamo G, Bauer P, et al. The ERA-Interim reanalysis: configuration and performance of the data assimilation system. Q J R Meteorol Soc 2011, 137:553-597. doi:10.1002/qj.828.

9. Wu L, Chou C, Chen C-T, Huang R, Knutson TR, Sirutis JJ, Garner ST, Kerr C, Lee C-J, Feng Y-C. Simulations of the present and late 21st century western North Pacific tropical cyclone activity using a regional model. J Clim 2014, 27:3405-3424. doi:10.1175/JCLI-D-12-00830.1.

10. Vecchi GA, Fueglistaler S, Held IM, Knutson TR, Zhao M. Impacts of atmospheric temperature changes on tropical cyclone activity. J Clim 2013, 26:3877-3891.

11. Kossin JP. Validating atmospheric reanalysis data using tropical cyclones as thermometers. Bull Am Meteorol Soc 2015, 96:1089-1096. doi:10.1175/ BAMS-D-14-00180.

12. Schenkel BA, Hart RE. An examination of tropical cyclone position, intensity, and intensity life cycle within atmospheric reanalysis datasets. J Clim 2012, 25:3453-3475.

13. Murakami H. Tropical cyclones in reanalysis data sets. Geophys Res Lett 2014, 41:2133-2141.

14. Liu K-B, Fearn ML. Reconstruction of prehistoric landfall frequencies of catastrophic hurricanes in northwestern Florida from lake sediment records. Quat Res 2000, 54:238-245.

15. Frappier AB. A stepwise screening system to select storm-sensitive stalagmites: taking a targeted approach to speleothem sampling. Quat Int 2007, 187:25-39. doi:10.1016/j.quanit.2007.09.042.
16. Donnelly JP, Hawkes AD, Lane P, MacDonald D, Shuman BN, Toomey MR, van Hengstum P, Woodruff JD. Climate forcing of unprecedented intense-hurricane activity in the last 2,000 years. Earth Future 2015, 3:49-65. doi:10.1002/ $2014 \mathrm{EF} 000274$.

17. Zhao M, Held IM, Lin S-J. Vecchi GA simulations of global hurricane climatology, interannual variability, and response to global warming using a $50-\mathrm{km}$ resolution GCM. J Clim 2009, 22:6653-6678.

18. Dunstone NJ, Smith DM, Booth BBB, Hermanson L, Eade R. Anthropogenic aerosol forcing of Atlantic tropical storms. Nat Geosci 2013, 6:534-539.

19. Murakami H, Wang Y, Yoshimura Y, Mizuta R, Sugi M, Shindo E, Adachi Y, Yukimoto S, Hosaka M, Kusunoki S, et al. Future changes in tropical cyclone activity projected by the new high-resolution MRIAGCM. J Clim 2012a, 25:3237-3260.

20. Murakami H, Vecchi GA, Underwood S, Delworth T, Wittenberg AT, Anderson W, Chen J-H, Gudgel R, Harris L, Lin S-J, et al. Simulation and prediction of category 4 and 5 hurricanes in the high-resolution GFDL HiFLOR coupled climate model. J Clim. In Press.

21. Bender M, Knutson T, Tuleya R, Sirutis J, Vecchi G, Garner ST, Held I. Modeled impact of anthropogenic warming on the frequency of intense Atlantic hurricanes. Science 2010, 327:454-458.

22. Zhao M, Held IM. An analysis of the effect of global warming on the intensity of Atlantic hurricanes use a GDM with statistical refinement. J Clim 2010, 23:6382-6393.

23. Villarini G, Vecchi GA. Projected increases in North Atlantic tropical cyclone intensity from CMIP5 models. J Clim 2013, 26:3231-3240.

24. Taylor KE, Stouffer RJ, Meehl GA. An overview of CMIP5 and the experiment design. Bull Am Meteorol Soc 2012, 93:485-498.

25. Emanuel KA. An air-sea interaction theory for tropical cyclones, part I: steady-state maintenance. J Atmos Sci 1986, 43:585-605.

26. Emanuel KA. The maximum intensity of hurricanes. J Atmos Sci 1988, 45:1143-1155.

27. IPCC. Stocker TF, Qin D, Plattner G-K, Tignor M, Allen SK, Boschung J, Nauels A, Xia Y, Bex V, Midgley PM, eds. Climate Change 2013: The Physical Science Basis. Contribution of Working Group I to the Fifth Assessment Report of the Intergovernmental Panel on Climate Change. Cambridge, UK and New York, NY: Cambridge University Press; 2013, $1535 \mathrm{pp}$.

28. Knutson TR, McBride JL, Chan J, Emanuel K, Holland G, Landsea C, Held I, Kossin JP, Srivastava AK, Sugi M. Tropical cyclones and climate change. Nat Geosci 2010， 3:157-163. doi:10.1038/ ngeo0779. 
29. Liu K-B. Chapter 2-paleotempestology: principles, methods, and examples from Gulf Coast lake sediments. In: Murnane RJ, Liu K-B, eds. Hurricanes and Typhoons, Past, Present and Future. New York: Columbia University Press; 2001, 13-57.

30. Brandon CM, Woodruff JD, Lane D, Donnelly JP. Tropical cyclone wind speed constraints from resultant storm surge deposition: a 2500 year reconstruction of hurricane activity from St. Marks, FL. Geochem Geophys Geosyst 2013, 14:2993-3008. doi:10.1002/ggge.20217.

31. Frappier A, Knutson T, Liu K-B, Emanuel K. Perspective: coordinating paleoclimate research on tropical cyclones with hurricane-climate theory and modelling. Tellus A 2007, 59:529-537.

32. Frappier AB, Pyburn J, Pinkey-Drobnis AD, Wang X, Corbett DR, Dahlin BH. Two millennia of tropical cyclone-induced mud layers in a northern Yucatán stalagmite: multiple overlapping climatic hazards during the Maya Terminal Classic "megadroughts." Geophys Res Lett 2014, 41:5148-5157.

33. Banholzer S, Kossin J, Donner S. The impact of climate change on natural disasters. In: Singh A, Zommers Z, eds. Preventing Disaster: Early Warning Systems for Climate Change. Dordrecht: Springer; 2014, 387 pp.

34. Woodruff JD, Donnelly JP, Emanuel K, Lane P. Assessing sedimentary records of paleohurricane activity using modeled hurricane climatology. Geochem Geophys Geosyst 2008, 9:Q09V10.

35. Haig J, Nott J, Reichart GJ. Australian tropical cyclone activity lower than at any time over the past 550-1,500 years. Nature 2014, 505:667-671.

36. Woodruff JD, Sriver SL, Lund DC. Tropical cyclone activity and western North Atlantic stratification over the last millennium: a comparative review with viable connections. J Quat Sci 2012, 27:337-343.

37. Kozar ME, Mann ME, Emanuel KA, Evans JL. Longterm variations of North Atlantic tropical cyclone activity downscaled from a coupled model simulation of the last millennium. J Geophys Res Atmos 2013, 118:13-383.

38. Mann ME, Woodruff JD, Donnelly JP, Zhang ZH. Atlantic hurricanes and climate over the past 1,500 years. Nature 2009, 460:880-883.

39. Fedorov AV, Breierly CM, Emanuel K. Tropical cyclones and permanent El Niño in the early Pliocene epoch. Nature 2010, 463:1066-1070.

40. Korty RL, Camargo SJ, Galewsky J. Variations in tropical cyclone genesis factors in simulations of the Holocene Epoch. J Clim 2012a, 25:8196-8211. doi:10.1175/JCLI-D-12-00033.1.

41. Korty RL, Camargo SJ, Galewsky J. Tropical cyclone genesis factors in simulations of the Last Glacial Maximum. J Clim 2012b, 25:4348-4365. doi:10.1175/JCLI-D-11-00517.1.
42. Sugi M, Yoshida K, Murakami H. More tropical cyclones in a cooler climate? Geophys Res Lett 2015, 42:6780-6784.

43. Held IM, Zhao M. The response of tropical cyclone statistics to an increase in $\mathrm{CO}_{2}$ with fixed sea surface temperatures. J Clim 2011, 24:5353-5364. doi:10.1175/JCLI-D-11-00050.1.

44. Merlis TM, Zhao M, Held IM. The sensitivity of hurricane frequency to ITCZ changes and radiatively forced warming in aquaplanet simulations. Geophys Res Lett 2013, 40:4109-4114.

45. Dare RA, McBride JL. The threshold sea surface temperature condition for tropical cyclogenesis. J Clim 2011, 24:4570-4576.

46. Merlis TM. Tropical cyclone frequency in simulations of the Last Glacial Maximum. Available at: https:// ams.confex.com/ams/31Hurr/webprogram/ Paper244915.html. (Accessed January 24, 2015).

47. Landsea CW, Feuer S, Hagen A, Glenn D, Sims J, Perez R, Chenoweth M, Anderson N. A reanalysis of the 1921-30 Atlantic hurricane database. J Clim 2012, 25:865-885.

48. Knapp KR, Knaff JA, Sampson CR, Riggio GM, Schnapp AD. A pressure-based analysis of the historical western North Pacific tropical cyclone intensity record. Mon Weather Rev 2013, 141:2611-2631.

49. Powell MD, Reinhold TA. Tropical cyclone destructive potential by integrated kinetic energy. Bull Am Meteorol Soc 2007, 88:513-526. doi:10.1175/ BAMS-88-4-513.

50. Czajkowski J, Done J. As the wind blows: understanding hurricane damages at the local level through a case study analysis. Weather Clim Soc 2014, 6:202-217. doi:10.1175/WCAS-D-13-00024.1.

51. Done J, Bruyère $\mathrm{C}, \mathrm{Ge} \mathrm{M}$, Holland GJ. Future changes in Gulf of Mexico hurricane wave climatology. In: OTC 2014 Offshore Technology Conference, Houston, TX, 5-8 May, 2014. Available at: http:// www.rpsea.org/media/files/project/cff96dc8/101214802-01-PR-Future_Changes_GOM_Hurricane_Wave_Climatology-05-07-14.pdf. (Accessed January 12, 2015).

52. Chang C-P, Yang Y-T, Kuo H-C. Large increasing trend of tropical cyclone rainfall in Taiwan and the roles of terrain. I Clim 2013, 26:4138-4147. doi:10.1175/JCLI-D-12-00463.1.

53. Knaff JA, Longmore SP, Molenar DA. An objective satellite-based tropical cyclone size climatology. J Clim 2014, 27:455-476.

54. Lloyd ID, Vecchi GA. Observational evidence for oceanic controls on hurricane intensity. J Clim 2011, 24:1138-1153.

55. Vincent EM, Emanuel KA, Lengaigne M, Vialard J, Madec G. Influence of upper-ocean stratification 
interannual variability on tropical cyclones. $J A d v$ Model Earth Syst 2014, 6:680-699.

56. Landsea CW, Harper BA, Hoarau K, Knaff JA. Can we detect trends in extreme tropical cyclones? Science 2006, 313:452-454.

57. Kamahori H, Yamazaki N, Mannoji N, Takahashi K. Variability in intense tropical cyclone days in the western North Pacific. SOLA 2006, 2:104-107.

58. Kossin JP, Emanuel KA, Vecchi GA. The poleward migration of the location of tropical cyclone maximum intensity. Nature 2014, 509:349-352.

59. Held IM, Hou AY. Nonlinear axially symmetric circulations in a nearly inviscid atmosphere. J Atmos Sci 1980, 37:515-533.

60. Lu J, Vecchi GA, Reichler T. Expansion of the Hadley cell under global warming. Geophys Res Lett 2007, 34:L06805.

61. Holland GJ, Bruyère C. Recent intense hurricane response to global climate change. Clim Dyn 2014, 42:617-627. doi:10.1007/s00382-013-1713-0.

62. Webster PJ, Holland GJ, Curry JA, Chang HR. Changes in tropical cyclone number, duration and intensity in a warming environment. Science 2005, 309:1844-1846.

63. Elsner JB, Kossin JP, Jagger TH. The increasing intensity of the strongest tropical cyclones. Nature 2008, 455:92-95.

64. Kang N-M, Elsner JB. Consensus on climate trends in western North Pacific tropical cyclones. J Clim 2012, 25:7564-7573.

65. Holland GJ, Webster PJ. Heightened tropical cyclone activity in the North Atlantic: natural variability or climate trend? Philos Trans R Soc Lond A 2007, 365:2695-2716.

66. Wu L, Zhao H. Dynamically derived tropical cyclone intensity changes over the Western North Pacific. J Clim 2012, 25:89-98.

67. Singh OP. Recent trends in tropical cyclone activity in the North Indian Ocean. In: Charabi Y, ed. Indian Ocean Tropical Cyclones and Climate Change. Dordrecht: Springer Science and Business; 2010, 51-54.

68. Elsner JB, Jagger TH. Hurricane Climatology: A Modern Statistical Guide Using R. New York: Oxford University Press; 2013, 380 pp.

69. Klotzbach PJ, Landsea CW. Extremely intense hurricanes: revisiting Webster et al. (2005) after 10 years. J Clim 2015, 28:7621-7629.

70. Maue RN. Recent historically low global tropical cyclone activity. Geophys Res Lett 2011, 38:L14803. doi:10.1029/2011GL047711.

71. Lee TC, Knutson TR, Kamahori H, Ying M. Impacts of climate change on tropical cyclones in the western North Pacific Basin, part I: past observations.
Tropical Cyclone Res Rev 2012a, 1:213-230. doi:10.6057/2012TCRR02.08.

72. Lee TC, Leung YY, Kok MH, Chan HS. The long term variations of tropical cyclone activity in the South China Sea and the vicinity of Hong Kong. Tropical Cyclone Res Rev 2012b, 1:277-292. doi:10.6057/2012TCRR02.01.

73. Ying M, Knutson TR, Kamahori H, Lee TC. Impacts of climate change on tropical cyclones in the Western North Pacific basin, part II: late 21st century projections. Tropical Cyclone Res Rev 2012, 1:231-241. doi:10.6057/2012TCRR02.09.

74. Song JJ, Wang Y, Wu L. Trend discrepancies among three best track data sets of western North Pacific tropical cyclones. J Geophys Res Atmos 2010, 115:D12128. doi:10.1029/2009JD013058.

75. Hsu P-C, Chu P-S, Murakami H, Zhao X. An abrupt decrease in the late-season typhoon activity over the western North Pacific. J Clim 2014, 27:4296-4312.

76. Choi Y, Ha K-J, Ho C-H, Chung CE. Interdecadal change in typhoon genesis condition over the western North Pacific. Clim Dyn. In press. doi:10.1007/ s00382-015-2536-y.

77. Liu KS, Chan JCL. Interdecadal variability of western North Pacific tropical cyclone tracks. J Clim 2008, 21:4464-4476.

78. Lucas C, Timbal B, Nguyen H. The expanding tropics: a critical assessment of the observational and modeling studies. WIREs Clim Change 2014, $5: 89-112$.

79. Zhao M, Held IM. TC-permitting GCM simulations of hurricane frequency response to sea surface temperature anomalies projected for the late-twenty-first century. J Clim 2012, 25:2995-3009. doi:10.1175/ JCLI-D-11-00313.1.

80. Walsh J, Wuebbles D, Hayhoe K, Kossin J, Kunkel K, Stephens G, Thorne P, Vose R, Wehner M, Willis J, et al. Chapter 2: our changing climate. In: Melillo JM, Richmond T, Yohe GW, eds. Climate Change Impacts in the United States: The Third National Climate Assessment. Washington DC: U.S. Global Change Research Program; 2014, 19-67.

81. Landsea CW, Vecchi GA, Bengtsson L, Knutson TR. Impact of duration thresholds on Atlantic tropical cyclone counts. J Clim 2010, 23:2508-2519.

82. Murakami H, Li T, Hsu P-C. Contributing factors to the recent high level of accumulated cyclone energy (ACE) and power dissipation index (PDI) in the North Atlantic. J Clim 2014, 27:3023-3034.

83. Goldenberg SB, Landsea CW, Mestas-Nuñez AM, Gray WM. The recent increase in Atlantic hurricane activity: causes and implications. Science 2001, 293:474-479.

84. Landsea C. Comment on "Monitoring and Understanding Trends in Extreme Storms-State of 
Knowledge”. Bull Am Meteorol Soc 2015, 96:11771179. doi:10.1175/BAMS-D-13-00211.1.

85. Bindoff NL, Stott PA, AchutaRao KM, Allen MR, Gillett N, Gutzler D, Hansingo K, Hegerl G, Hu Y, Jain S, et al. Detection and attribution of climate change: from global to regional. In: Stocker TF, Qin D, Plattner G-K, Tignor M, Allen SK, Boschung J, Nauels A, Xia Y, Bex V, Midgley PM, eds. Climate Change 2013: The Physical Science Basis. Contribution of Working Group I to the Fifth Assessment Report of the Intergovernmental Panel on Climate Change. Cambridge, UK and New York, NY: Cambridge University Press; 2013, 1535 pp.

86. Mann ME, Emanuel KA. Atlantic hurricane trends linked to climate change. Eos 2006, 87:233-244.

87. Booth BBB, Dunstone NJ, Halloran PR, Andrews T, Bellouin N. Aerosols implicated as a prime driver of twentieth-century North Atlantic climate variability. Nature 2012, 484:228-232.

88. Zhang R, Delworth TL, Sutton R, Hodson D, Dixon KW, Held IM, Kushnir Y, Marshall D, Ming Y, Msadek $\mathrm{R}$, et al. Have aerosols caused the observed Atlantic multidecadal variability? I Atmos Sci 2013, 70:1135-1144

89. Mann ME, Steinman BA, Miller SK. On forced temperature changes, internal variability, and the AMO. Geophys Res Lett 2014, 41:3211-3219. doi:10.1002/2014GL059233.

90. Knight JR, Allan RJ, Folland CK, Vellinga M, Mann ME. A signature of persistent natural thermohaline circulation cycles in observed climate. Geophys Res Lett 2005, 32:L20708. doi:10.1029/2005GL024233.

91. Zhang R, Delworth TL. Impact of Atlantic multidecadal oscillations on India/Sahel rainfall and Atlantic hurricanes. Geophys Res Lett 2006, 33:L17712. doi:10.1029/2006GL026267.

92. Klotzbach PJ, Gray WM. Multidecadal variability in North Atlantic tropical cyclone activity. J Clim 2008, 21:3929-3935.

93. Delworth TL, Mann ME. Observed and simulated multidecadal variability in the Northern Hemisphere. Clim Dyn 2000, 16:661-676.

94. Evan AT. Atlantic hurricane activity following two major volcanic eruptions. I Geophys Res Atmos 2012, 117:D06101. doi:10.1029/2011JD016716.

95. Evan AT, Foltz GR, Zhang D, Vimont DJ. Influence of African dust on ocean-atmosphere variability in the tropical Atlantic. Nat Geosci 2011, 4:762-765.

96. Evan AT, Vimont DJ, Heidinger AK, Kossin JP, Bennartz $\mathrm{R}$. The role of aerosols in the evolution of tropical North Atlantic Ocean temperature anomalies. Science 2009, 324:778-781.

97. Emanuel K, Solomon S, Folini D, Davis S, Cagnazzo C. Influence of tropical tropopause layer cooling on
Atlantic hurricane activity. I Clim 2013, 26:22882301. doi:10.1175/JCLI-D-12-00242.1.

98. Kalnay E, Kanamitsu M, Kistler R, Collins W, Deaven $\mathrm{D}$, Gandin L, Iredell M, Saha S, White G, Woollen J, et al. The NCEP/NCAR 40-year reanalysis project. Bull Am Meteorol Soc 1996, 77:437-471.

99. Grinsted A, Moore JC, Jevrejeva S. Homogeneous record of Atlantic hurricane surge threat since 1923. Proc Natl Acad Sci USA 2012, 109:19601-19605.

100. Peduzzi P, Chatenoux B, Dao H, De Bono A, Herold $\mathrm{C}$, et al. Global trends in tropical cyclone risk. Nat Clim Change 2012, 2:289-294.

101. Srivastava AK, Sinha Ray KC, De US. Trends in the frequency of cyclonic disturbances and their intensification over Indian sea. Mausam 2000, 51:113-118.

102. Singh OP, Khan TMA, Rahman MS. Changes in the frequency of tropical cyclones over the North Indian Ocean. Meteorol Atmos Phys 2000, 75:11-20.

103. Niyas NT, Srivastava AK, Hatwar HR. Variability and trend in the cyclonic storms over North Indian Ocean. Meteorological Monograph No. Cyclone Warning-3/2009, 2009, 35 pp. Available at: http:// www.imdpune.gov.in/ncc_rept/Met_Monograph\% 20No.\%203_2009.pdf. (Accessed January 20, 2015).

104. Geetha B, Balachandran S. Decadal variations in translational speeds of cyclonic disturbances over North Indian Ocean. Mausam 2014, 65:115-118.

105. Evan AT, Kossin JP, Chung CE, Ramanathan V. Arabian Sea tropical cyclones intensified by emissions of black carbon and other aerosols. Nature 2011, 479:94-97.

106. Evan AT, Kossin JP, Chung C, Ramanathan V. Intensified Arabian Sea tropical storms. Nature 2012, 2012:E2-E3.

107. Wang B, Xu S, Wu L. Intensified Arabian Sea tropical storms. Nature 2012, 489:E1-E2. doi:10.1038/ nature11470.

108. Raghavan S, Rajesh S. Trends in tropical cyclone impact: a study in Andhra Pradesh, India. Bull Am Meteorol Soc 2003, 84:635-644. doi:10.1175/ BAMS-84-5-635.

109. Callaghan J, Power SB. Variability and decline in the number of severe tropical cyclones making land-fall over eastern Australia since the late nineteenth century. Clim Dyn 2011, 37:647-662.

110. Hartmann DL, Klein Tank AMG, Rusticucci M, Alexander LV, Brönnimann S, Charabi Y, Dentener FJ, Dlugokencky EJ, Easterling DR, Kaplan A, et al. Observations: atmosphere and surface. In: Stocker TF, Qin D, Plattner G-K, Tignor M, Allen SK, Boschung J, Nauels A, Xia Y, Bex V, Midgley PM, eds. Climate Change 2013: The Physical Science Basis. Contribution of Working Group I to the Fifth Assessment Report of the Intergovernmental Panel on 
Climate Change. Cambridge, UK and New York, NY: Cambridge University Press; 2013.

111. Kuleshov YR, Fawcett R, Qi L, Trewin B, Jones D, McBride J, Ramsay H. Trends in tropical cyclones in the South Indian Ocean and the South Pacific Ocean. J Geophys Res Atmos 2010, 115:D01101. doi:10.1029/2009JD012372.

112. Malan N, Reason CJC, Loveday BR. Variability in tropical cyclone heat potential over the Southwest Indian Ocean. J Geophys Res Oceans 2013, 118:6734-6746. doi:10.1002/2013JC008958.

113. Klotzbach PJ. Trends in global tropical cyclone activity over the past twenty years (1986-2005). Geophys Res Lett 2006, 33:L10805. doi:10.1029/ 2006 GL025881.

114. Raga GB, Bracamontes-Ceballos B, Farfán L, Romero-Centeno R. Landfalling tropical cyclones on the Pacific coast of Mexico: 1850-2010. Atmosfera 2013, 26:209-220.

115. Mantua NJ, Hare SR. The Pacific decadal oscillation. J Oceanogr 2002, 58:35-44.

116. Pazos M, Mendoza B. Landfalling tropical cyclones along the eastern Pacific coast between the sixteenth and twentieth centuries. J Clim 2013, 26:4219-4230.

117. Camargo SJ, Sobel AH, Barnston AG, Klotzbach PJ. Chapter 11: the influence of natural climate variability, and seasonal forecasts of tropical cyclone activity. In: Chan JCL, Kepert JD, eds. Global Perspectives on Tropical Cyclones, from Science to Mitigation. World Scientific Series on Earth System Science in Asia, vol. 4. 2nd ed. Singapore: World Scientific; 2010, 325-360. ISBN: 978-981-4293-47-1.

118. Klotzbach PJ. The influence of El Niño-Southern oscillation and the Atlantic multidecadal oscillation on Caribbean tropical cyclone activity. J Clim 2011, 24:721-731.

119. Zhang G, Wang Z. Interannual variability of the Atlantic Hadley circulation in boreal summer and its impacts on tropical cyclone activity. J Clim 2013, 26:8529-8544.

120. Diamond HJ, Lorrey AM, Renwick JA. A southwest Pacific tropical cyclone climatology and linkages to the El Niño-Southern Oscillation. J Clim 2013, $26: 3-25$

121. Chand SS, Tory KJ, McBride J, Wheeler MC, Dare $\mathrm{R}$, Walsh KJE. The different impact of positiveneutral and negative-neutral ENSO regimes on Australian tropical cyclones and rainfall. J Clim 2013, 26:8008-8016.

122. Felton CS, Subrahmanyam B, Murty VSN. ENSOmodulated cyclogenesis over the Bay of Bengal. J Clim 2013, 26:9806-9818.

123. Chen JH, Lin S-J. The remarkable predictability of interannual variability of Atlantic hurricanes during the past decades. Geophys Res Lett 2011, 38: L11804. doi:10.1029/2011GL047629.

124. Wang H, Long L, Kumar A, Wang W, Schemm J-KE, Zhao M, Vecchi GA, LaRow TE, Lin Y-K, Schubert $\mathrm{SD}$, et al. How well do global climate models simulate the variability of Atlantic tropical cyclones associated with ENSO? J Clim 2014, 27:5673-5692.

125. Vecchi GA, Delworth T, Gudgel R, Kapnick S, Rosati A, Wittenberg AT, Zeng F, Anderson W, Balaji V, Dixon $\mathrm{K}$, et al. On the seasonal forecasting of regional tropical cyclone activity. J Clim 2014, 27:7994-8016. doi:10.1175/JCLI-D-14-00158.1.

126. Bell R, Hodges K, Vidale PL, Strachan J, Roberts M. Simulation of the global ENSO-tropical cyclone teleconnection by a high-resolution coupled general circulation model. J Clim 2014, 27:6404-6422.

127. Walsh KJE. Fine resolution simulations of the effect of climate change on tropical cyclones in the South Pacific. Clim Dyn 2015, 45:2619-2631.

128. Christensen JH, Krishna Kumar K, Aldrian E, An S-I, Cavalcanti IFA, de Castro M, Dong W, Goswami P, Hall A, Kanyanga JK, et al. Climate phenomena and their relevance for future regional climate change. In: Stocker TF, Qin D, Plattner G-K, Tignor M, Allen SK, Boschung J, Nauels A, Xia Y, Bex V, Midgley PM, eds. Climate Change 2013: The Physical Science Basis. Contribution of Working Group I to the Fifth Assessment Report of the Intergovernmental Panel on Climate Change (IPCC AR5). Cambridge, UK and New York, NY: Cambridge University Press; 2013.

129. Sugi M, Murakami H, Yoshimura J. On the mechanism of tropical cyclone frequency changes due to global warming. I Meteorol Soc Jpn 2012, 90A:397-408.

130. Zhao M, Held IM, Vecchi G, Scoccimarro E, Wang $\mathrm{H}$, Wehner M, Lim Y-K, LaRow T, Camargo SJ, Walsh $\mathrm{K}$, et al. Robust direct effect of increasing atmospheric $\mathrm{CO}_{2}$ concentration on global tropical cyclone frequency-a multi-model inter-comparison. CLIVAR Variations 2013, 11:17-23. Available at: http:/www.usclivar.org/sites/default/files/USCLIVAR_VARIATIONS_11_3_Fall2013.pdf. (Accessed December 5, 2013).

131. Rappin ED, Nolan DS, Emanuel KA. Thermodynamic control of tropical cyclogenesis in environments of radiative-convective equilibrium with shear. Q J R Meteorol Soc 2010, 136:1954-1971.

132. Bruyère CL, Holland GJ, Towler E. Investigating the use of a genesis potential index for tropical cyclones in the North Atlantic Basin. J Clim 2012, 25:8611-8626.

133. Walsh KJE, Camargo SJ, Vecchi GA, Daloz AS, Elsner J, Emanuel K, Horn M, Lim Y-K, Roberts M, Patricola C, et al. Hurricanes and climate: the U.S. CLIVAR working group on hurricanes. Bull Am Meteorol Soc 2015, 96:997-1017. 
134. Satoh M, Yamada Y. Constraint on future change of number of tropical cyclones associated with global warming. J Meteorol Soc Jpn. In press.

135. Menkes CE, Lengaigne M, Marchesiello P, Jourdain NC, Vincent EM, Lefevre J, Chauvin F, Royer J-F. Comparison of tropical cyclogenesis indices on seasonal to interannual timescales. Clim Dyn 2012, 38:301-321.

136. Tippett MK, Camargo SJ, Sobel AH. A Poisson regression index for tropical cyclone genesis and the role of large-scale vorticity in genesis. J Clim 2011, 24:2335-2357.

137. Emanuel KA, Nolan DS. Tropical cyclone activity and global climate. In: Proceedings of the 26th Conference on Hurricanes and Tropical Meteorology, American Meteorological Society, Miami, FL, 2004, 240-241. Available at: ftp://texmex.mit.edu/pub/emanuel/PAPERS/em_nolan_extended_2004.pdf.

(Accessed October 10, 2015).

138. Emanuel K. Tropical cyclone activity downscaled from NOAA-CIRES reanalysis, 1908-1958. I Adv Model Earth Syst 2010, 2.

139. Camargo SJ, Tippett MK, Sobel AH, Vecchi GA, Zhao M. Testing the performance of tropical cyclone genesis indices in future climates using the HIRAM model. J Clim 2014, 27:9171-9196.

140. Peng MS, Fu B, Li T, Stevens DE. Developing versus nondeveloping disturbances in the North Atlantic and Western North Pacific, part I: the North Atlantic. Mon Weather Rev 2012, 140:1047-1066. doi:10.1175/2011MWR3617.1.

141. Bister M, Emanuel KA. Dissipative heating and hurricane intensity. Meteorol Atmos Phys 1998, 65:233-240.

142. Tang B, Emanuel K. Sensitivity of tropical cyclone intensity to ventilation in an axisymmetric model. J Atmos Sci 2012, 69:2394-2413.

143. Emanuel K, Sobel A. Response of tropical sea surface temperature, precipitation, and tropical cyclonerelated variables to changes in global and local forcing. J Adv Model Earth Syst 2013, 5:447-458.

144. Camargo SJ, Ting M, Kushnir Y. Influence of local and remote SST on North Atlantic tropical cyclone potential intensity. Clim Dyn 2013, 40:1515-1529.

145. Ting M, Camargo SJ, Li C, Kushnir Y. Natural and forced North Atlantic hurricane potential intensity change in CMIP5 models. J Clim 2015, 28:3926-3942.

146. Villarini G, Vecchi GA. Twenty-first-century projections of North Atlantic tropical storms from CMIP5 models. Nat Clim Change 2012, 2:604-607.

147. Knutson TR, Sirutis JJ, Vecchi GA, Garner S, Zhao M, Kim H-S, Bender M, Tuleya RE, Held IM, Villarini G. Dynamical downscaling projections of late 21st century Atlantic hurricane activity: CMIP3 and
CMIP5 model-based scenarios. I Clim 2013, 26:6591-6617. doi:10.1175/JCLI-D-12-00539.1-.

148. Ramsay HA. The effects of imposed stratospheric cooling on the maximum intensity of tropical cyclones in axisymmetric radiative-convective equilibrium. J Clim 2013, 26:9977-9985.

149. Wang S, Camargo SJ, Sobel AH, Polvani LM. Impact of the tropopause temperature on the intensity of tropical cyclones-an idealized study using a mesoscale model. J Atmos Sci 2014, 71:4333-4348.

150. Bell R, Strachan J, Vidale PL, Hodges K, Roberts M. Response of tropical cyclones to idealized climate change experiments in a global high-resolution coupled general circulation model. I Clim 2013, 26:7966-7980.

151. Shaevitz DA, Camargo SJ, Sobel AH, Jonas JA, Kim D, Kumar A, LaRow TE, Lim Y-K, Murakami H, Reed K, et al. Characteristics of tropical cyclones in high-resolution models in the present climate. $J A d v$ Model Earth Syst 2014, 6:1154-1172.

152. Tory KJ, Dare RA, Davidson NE, McBride JL, Chand SS. The importance of low-deformation vorticity in tropical cyclone formation. Atmos Chem Phys 2013a, 13:2115-2132.

153. Tory KJ, Chand SS, Dare RA, McBride JL. An assessment of a model-, grid-, and basin-independent tropical cyclone detection scheme in selected CMIP3 global climate models. J Clim 2013c, 26:5508-5522.

154. Mei W, Xie S, Zhao M. Variability of tropical cyclone track density in the North Atlantic: observations and high-resolution simulations. J Clim 2014, 27:4797-4814. doi:10.1175/JCLI-D-13-00587.1.

155. Sugi M, Yoshimura J. Decreasing trend of tropical cyclone frequency in 228-year high-resolution AGCM simulations. Geophys Res Lett 2012, 39:L19805. doi:10.1029/2012GL053360.

156. Tory KJ, Chand SS, McBride JL, Ye H, Dare RA. Projected changes in late 21 st century tropical cyclone frequency in CMIP5 models. In: Proceedings of the 31st Conference on Hurricanes and Tropical Meteorology, American Meteorological Society, San Diego, CA, 2014, 7C.4. Available at: https://ams.confex. com/ams/31Hurr/webprogram/Paper245100.html. (Accessed September 6, 2014).

157. Murakami H, Hsu P-C, Arakawa O, Li Y. Influence of model biases on projected future changes in tropical cyclone frequency of occurrence. J Clim 2014, 27:2159-2181.

158. Camargo SJ. Global and regional aspects of tropical cyclone activity in the CMIP5 models. J Clim 2013, 26:9880-9902. doi:10.1175/JCLI-D-12-00549.1.

159. Tory KJ, Chand SS, Dare RA, McBride JL. The development and assessment of a model-, grid-, and basinindependent tropical cyclone detection scheme. J Clim 2013b, 26:5493-5507. 
160. Murakami H, Mizuta R, Shindo E. Future changes in tropical cyclone activity projected by multi-physics and multi-SST ensemble experiments using the 60km-mesh MRI-AGCM. Clim Dyn 2012b, 39:25692584. doi:10.1007/s00382-011-1223-x.

161. Strachan J, Vidale PL, Hodges K, Roberts M, Demory M-E. Investigating global tropical cyclone activity with a hierarchy of AGCMs: the role of model resolution. J Clim 2013, 26:133-152. doi:10.1175/JCLI-D12-00012.1.

162. Rathmann NM, Yang S, Kaas E. Tropical cyclones in enhanced resolution CMIP5 experiments. Clim Dyn 2013, 42:665-681.

163. Emanuel KA. Downscaling CMIP5 climate models shows increased tropical cyclone activity over the 21st century. Proc Natl Acad Sci USA 2013, 110. doi:10.1073/pnas.1301293110.

164. Li T, Kwon M, Zhao M, Kug J-S, Luo J-J, Yu W. Global warming shifts Pacific tropical cyclone location. Geophys Res Lett 2010, 37:L21804. doi:10.1029/2010GL045124.

165. Murakami H, Wang B, Li T, Kitoh A. Projected increase in tropical cyclones near Hawaii. Nat Clim Change 2013, 3:749-754.

166. Murakami H, Sugi M, Kitoh A. Future changes in tropical cyclone activity in the North Indian Ocean projected by high-resolution MRI-AGCMs. Clim Dyn 2013, 40:1949-1968.

167. Tang B, Camargo SJ. Environmental control of tropical cyclones in CMIP5: a ventilation perspective. J Adv Model Earth Syst 2014, 6:115-128. doi:10.1002/2013MS000294.

168. Evans JL, Waters JJ. Simulated relationships between sea surface temperatures and tropical convection in climate models and their implications for tropical cyclone activity. J Clim 2012, 25:7884-7895.

169. Vecchi GA, Soden BJ. Effect of remote sea surface temperature change on tropical cyclone potential intensity. Nature 2007, 450:1066-1070. doi:10.1038/nature06423.

170. Johnson NC, Xie SP. Changes in the sea surface temperature threshold for tropical convection. Nat Geosci 2010, 3:842-845.

171. Colbert AJ, Soden BJ, Vecchi GA, Kirtman BP. The impact of anthropogenic climate change on North Atlantic tropical cyclone tracks. J Clim 2013, 26:4088-4095.

172. Murakami H, Wang B. Future change of North Atlantic tropical cyclone tracks: projection by a $20-$ km-mesh global atmospheric model. J Clim 2010, 23:2699-2721.

173. Wang R, Wu L, Wang C. Typhoon track changes associated with global warming. J Clim 2011, 24:3748-3752.
174. Murakami H, Wang B, Kitoh A. Future change of western North Pacific typhoons: projections by a 20km-mesh global atmospheric model. J Clim 2011, 24:1154-1169.

175. Yokoi S, Takayabu YN. Attribution of projected future changes in tropical cyclone passage frequency over the Western North Pacific. J Clim 2013, 26:4096-4111.

176. Lavender SL, Walsh KJE. Dynamically downscaled simulations of Australian region tropical cyclones in current and future climates. Geophys Res Lett 2011, 38. doi:10.1029/2011GL047499.

177. Manganello JV, Hodges KI, Kinter JL III, Cash BA, Marx L, Jung T, Achuthavarier D, Adams JM, Altshuler EL, Huang B, et al. Tropical cyclone climatology in a $10-\mathrm{km}$ global atmospheric GCM: toward weather-resolving climate modeling. I Clim 2012, 25:3867-3893. doi:10.1175/JCLI-D-11-00346.1.

178. Knutson TR, Sirutis JJ, Zhao M, Tuleya RE, Bender M, Vecchi GA, Villarini G, Chavas D. Global projections of intense tropical cyclone activity for the late 21st century from dynamical downscaling of CMIP5/ RCP4.5 scenarios. J Clim 2015, 28:7203-7224.

179. Kanada S, Wada A, Sugi M. Future changes in structures of extremely intense tropical cyclones using a 2$\mathrm{km}$ mesh nonhydrostatic model. I Clim 2013, 26:9986-10005. doi:10.1175/JCLI-D-12-00477.1.

180. Tsuboki K, Yoshioka M, Shinoda T, Kato M, Kanada S, Kitoh A. Future increase of super-typhoon intensity associated with climate change. Geophys Res Lett 2014, 42:646-652.

181. Emanuel KA. The theory of hurricanes. Annu Rev Fluid Mech 1991, 23:179-196.

182. Strazzo SE, Elsner JB, LaRow T, Halperin DJ, Zhao M. Observed versus GCM-generated local tropical cyclone frequency: comparisons using a spatial lattice. J Clim 2013, 26:8257-8268.

183. Kim H-S, Vecchi GA, Knutson TR, Anderson WG, Delworth TL, Rosati A, Zeng F, Zhao M. Tropical cyclone simulation and response to $\mathrm{CO}_{2}$ doubling in the GFDL CM2.5 high-resolution coupled climate model. J Clim 2014, 27:8034-8054. doi:10.1175/ JCLI-D-13-00475.1.

184. Scoccimarro E, Gualdi S, Bellucci A, Sanna A, Fogli PG, Manzini E, Vichi M, Oddo P, Navarra A. Effects of tropical cyclones on ocean heat transport in a high resolution coupled general circulation model. J Clim 2011, 24:4368-4384. doi:10.1175/2011JCLI4104.1.

185. Bueti MR, Ginis I, Rothstein LM, Griffies SM. Tropical cyclone-induced thermocline warming and its regional and global impacts. J Clim 2014, 27:6978-6999.

186. Villarini G, Lavers DA, Scoccimarro E, Zhao M, Wehner MF, Vecchi G, Knutson T. Sensitivity of tropical cyclone rainfall to idealized global scale forcings. J Clim 2014, 27:4622-4641. 
187. Scoccimarro E, Gualdi S, Villarini G, Vecchi G, Zhao M, Walsh K, Navarra A. Intense precipitation events associated with landfalling tropical cyclones in response to a warmer climate and increased $\mathrm{CO}_{2}$. J Clim 2014, 27:4642-4654.

188. Peterson TC, Karl TR, Kossin JP, Kunkel KE, Lawrimore JH, McMahon JR, Vose RS, Yin X. Changes in weather and climate extremes: state of knowledge relevant to air and water quality in the United States. J Air Waste Manage Assoc 2014, 64:184-197. doi:10.1080/10962247.2013.851044.

189. Lin N, Emanuel K, Oppenheimer M, Vanmarcke E. Physically based assessment of hurricane surge threat under climate change. Nat Clim Change 2012, 2:462-467.

190. Woodruff JD, Irish JL, Camargo SJ. Coastal flooding by tropical cyclones and sea-level rise. Nature 2013, 504:44-52. doi:10.1038/nature12855.

191. McInnes K, Walsh K, Hoeke RK, O’Grady JG, Colberg F. Quantifying storm tide risk in Fiji due to climate variability and change. Glob Planet Change 2014, 116:115-129.

192. Tebaldi C, Strauss BH, Zervas CE. Modelling sea level rise impacts on storm surges along US coasts. Environ Res Lett 2012, 7:014032.

193. Horn M, Walsh K, Zhao M, Camargo SJ, Scoccimarro E, Murakami H, Wang H, Ballinger A, Kumar
A, Shaevitz D, et al. Tracking scheme dependence of simulated tropical cyclone response to idealized climate simulations. J Clim 2014, 27:9197-9213.

194. Walsh K, Fiorino M, Landsea C, McInnes K. Objectively-determined resolution-dependent threshold criteria for the detection of tropical cyclones in climate models and reanalyses. J Clim 2007, 20:2307-2314.

195. Camargo SJ, Zebiak SE. Improving the detection and tracking of tropical cyclones in atmospheric general circulation models. Weather Forecast 2002, 17:1152-1162.

196. Lander MA. Description of a monsoon gyre and its effects on the tropical cyclones in the western North Pacific during August 1991. Weather Forecast 1994, 9:640-654.

197. Park DSR, Ho CH, Kim HS, Kim JH. Spatially inhomogeneous trends of tropical cyclone intensity over the Western North Pacific for 1977-2010. J Clim 2013, 26:5088-5101.

198. Park DSR, Ho CH, Kim JH. Growing threat of intense tropical cyclones to East Asia over the period 1977-2010. Environ Res Lett 2014, 9:014008.

199. Sugi M, Murakami H. Bias correction for regional projections of tropical cyclone intensity changes. In: AOGS 11th Annual Meeting, 28 July-1 August, 2014, Sapporo, Japan. 